\title{
Composition and vertical flux of particulate organic matter to the oxygen minimum zone of the central Baltic Sea: impact of a sporadic North Sea inflow
}

\author{
Carolina Cisternas-Novoa $^{1}$, Frédéric A. C. Le Moigne ${ }^{1, a}$, and Anja Engel ${ }^{1}$ \\ ${ }^{1}$ GEOMAR, Helmholtz Centre for Ocean Research Kiel, Düsternbrooker Weg 20, 24105 Kiel, Germany \\ apresent address: Mediterranean Institute of Oceanography, UM 110, Aix Marseille Univ., \\ Universiteì 6 de Toulon, CNRS, IRD, 13288, Marseille, France
}

Correspondence: Carolina Cisternas-Novoa (ccisternas@geomar.de)

Received: 26 July 2018 - Discussion started: 6 August 2018

Revised: 21 January 2019 - Accepted: 6 February 2019 - Published: 27 February 2019

\begin{abstract}
Particle sinking is a major form of transport for photosynthetically fixed carbon to below the euphotic zone via the biological carbon pump (BCP). Oxygen $\left(\mathrm{O}_{2}\right)$ depletion may improve the efficiency of the BCP. However, the mechanisms by which $\mathrm{O}_{2}$ deficiency can enhance particulate organic matter (POM) vertical fluxes are not well understood. Here, we investigate the composition and vertical fluxes of POM in two deep basins of the Baltic Sea (GB: Gotland Basin and LD: Landsort Deep). The two basins showed different $\mathrm{O}_{2}$ regimes resulting from the intrusion of oxygenrich water from the North Sea that ventilated the water column below $140 \mathrm{~m}$ in $\mathrm{GB}$, but not in $\mathrm{LD}$, during the time of sampling. In June 2015, we deployed surface-tethered drifting sediment traps in oxic surface waters (GB: 40 and $60 \mathrm{~m}$; LD: 40 and $55 \mathrm{~m}$ ), within the oxygen minimum zone (OMZ; GB: $110 \mathrm{~m}$ and LD: 110 and $180 \mathrm{~m}$ ) and at recently oxygenated waters by the North Sea inflow in GB $(180 \mathrm{~m})$. The primary objective of this study was to test the hypothesis that the different $\mathrm{O}_{2}$ conditions in the water column of GB and LD affected the composition and vertical flux of sinking particles and caused differences in export efficiency between those two basins.

The composition and vertical flux of sinking particles were different in GB and LD. In GB, particulate organic carbon (POC) flux was $18 \%$ lower in the shallowest trap $(40 \mathrm{~m})$ than in the deepest sediment trap (at $180 \mathrm{~m}$ ). Particulate nitrogen (PN) and Coomassie stainable particle (CSP) fluxes decreased with depth, while particulate organic phosphorus (POP), biogenic silicate (BSi), chlorophyll $a(\mathrm{Chl} a$ ) and transparent exopolymeric particle (TEP) fluxes peaked
\end{abstract}

within the core of the OMZ $(110 \mathrm{~m})$; this coincided with the presence of manganese oxide-like (MnOx-like) particles aggregated with organic matter. In LD, vertical fluxes of POC, PN and CSPs decreased by $28 \%, 42 \%$ and $56 \%$, respectively, from the surface to deep waters. POP, BSi and TEP fluxes did not decrease continuously with depth, but they were higher at $110 \mathrm{~m}$. Although we observe a higher vertical flux of POP, BSi and TEPs coinciding with abundant MnOx-like particles at $110 \mathrm{~m}$ in both basins, the peak in the vertical flux of POM and MnOx-like particles was much higher in GB than in LD. Sinking particles were remarkably enriched in $\mathrm{BSi}$, indicating that diatoms were preferentially included in sinking aggregates and/or there was an inclusion of lithogenic Si (scavenged into sinking particles) in our analysis. During this study, the POC transfer efficiency (POC flux at $180 \mathrm{~m}$ over $40 \mathrm{~m}$ ) was higher in GB (115\%) than in LD $(69 \%)$, suggesting that under anoxic conditions a smaller portion of the POC exported below the euphotic zone was transferred to $180 \mathrm{~m}$ than under reoxygenated conditions present in GB. In addition, the vertical fluxes of MnOx-like particles were 2 orders of magnitude higher in GB than LD. Our results suggest that POM aggregates with MnOx-like particles formed after the inflow of oxygen-rich water into $\mathrm{GB}$, and the formation of those $\mathrm{MnOx}-\mathrm{OM}$-rich particles may alter the composition and vertical flux of POM, potentially contributing to a higher transfer efficiency of POC in GB. This idea is consistent with observations of fresher and less degraded organic matter in deep waters of GB than LD. 


\section{Introduction}

Particle sinking is the primary mechanism for transporting photosynthetically fixed carbon below the euphotic zone via the biological carbon pump (BCP) (Boyd and Trull, 2007; Turner, 2015). Previous studies suggested that the transfer of particulate organic carbon (POC) from the euphotic zone to the ocean interior is enhanced in oxygen minimum zones (OMZs) (Cavan et al., 2017; Devol and Hartnett, 2001; Engel et al., 2017; Keil et al., 2016; Van Mooy et al., 2002). Possible mechanisms explaining the higher POC transfer include the following: (i) the reduction of aggregate fragmentation due to the lower zooplankton abundance within the OMZ (Cavan et al., 2017; Keil et al., 2016); (ii) the potentially high contribution of refractory terrestrial organic matter (OM) to the POC flux (Keil et al., 2016; Van Mooy et al., 2002); (iii) a decrease in heterotrophic microbial activity due to oxygen $\left(\mathrm{O}_{2}\right)$ limitation (Devol and Hartnett, 2001); (iv) the preferential degradation of nitrogen-rich organic compounds (Kalvelage et al., 2013; Van Mooy et al., 2002; Engel et al., 2017); and (v) changes in ballast materials that may alter the sinking velocity and protect $\mathrm{OM}$ from degradation (Armstrong et al., 2002). Currently, the study of POC vertical flux in OMZs has been mostly focused on the tropical ocean (Cavan et al., 2017; Devol and Hartnett, 2001; Engel et al., 2017; Keil et al., 2016; Van Mooy et al., 2002), whereas how low $\mathrm{O}_{2}$ concentration would affect the composition and fate of sinking $\mathrm{OM}$, and the efficiency of the BCP in oxygen-deficient zones of temperate-boreal regimes such as the Baltic deep basins, has been less studied.

The semi-enclosed, brackish Baltic Sea is a unique environment with strong natural gradients of salinity and temperature (Kullenberg and Jacobsen, 1981), primary productivity, nutrients (Andersen et al., 2017), and $\mathrm{O}_{2}$ concentrations (Carstensen et al., 2014a). New production, defined as the fraction of the autotrophic production supported by allochthonous sources of nitrogen (Dugdale and Goering, 1967), is considered equivalent to the particulate OM export (Eppley and Peterson, 1979; Legendre and Gosselin, 1989) on appropriate timescales. In the Baltic Sea, new production varies seasonally (Thomas and Schneider, 1999), with periods of high new production during spring and summer, supported by the diatom-dominated spring bloom and by diazotrophic cyanobacteria, respectively (Wasmund and Uhlig, 2003). Based on sediment trap data collected at $140 \mathrm{~m}$ of depth in the Gotland Basin (GB), Struck et al. (2004) reported that the highest fluxes of POC occurred in fall, followed by summer and spring. Using $\delta^{15} \mathrm{~N}$, they showed that during the summer, $\mathrm{N}_{2}$ fixation by diazotrophic species is the primary source $(\sim 41 \%)$ of the exported nitrogen and that the majority of the sedimentary particulate organic matter (POM) in the central Baltic Sea is of pelagic origin.

OM export from the euphotic zone to the seafloor has a dual significance in the deep basins of the Baltic Sea. On the one hand, it contributes to the long-term burial of POC and consequently to the removal and long-term storage of $\mathrm{CO}_{2}$ from surface waters (Emeis et al., 2000; Leipe et al., 2011); on the other hand, it connects the pelagic and the benthic systems contributing to the $\mathrm{O}_{2}$ consumption and hence deoxygenation at depth. Environmental and anthropogenic changes may alter the magnitude and composition of OM transferred from the surface to the seafloor in the Baltic Sea (Tamelander et al., 2017). The reduction of nutrient inputs as targeted by the Baltic Marine Environment Protection Commission (HELCOM) may reduce the OM downward flux and limit the oxygen depletion at depth. However, since hypoxia occurred naturally in the Baltic Sea due to physical processes, mitigating eutrophication will only decrease the spatial extent and intensity of the $\mathrm{O}_{2}$ deficiency in the deep basins.

GB (248 m) and Landsort Deep (LD; $460 \mathrm{~m}$ ) are the deepest basins of the Baltic Sea. They exhibit permanent bottomwater hypoxia (Conley et al., 2009) caused by a combination of limited water exchange with the North Sea through the Kattegat, strong vertical stratification, and high productionremineralization of OM due to eutrophication (Carstensen et al., 2014b; Conley et al., 2009). A permanent transition zone of about 2 to $10 \mathrm{~m}$ thickness separates the oxygenated surface and the oxygen-deficient waters, with a pelagic redoxcline located approximately between 127 and $129 \mathrm{~m}$ in GB and between 79 and $85 \mathrm{~m}$ in LD (Glockzin et al., 2014). From the 1950s to 1970s, the hypoxic zones $(<60 \mu \mathrm{M})$ in the Baltic Sea expanded fourfold (Carstensen et al., 2014a). Saltwater inflows from the North Sea are the primary mechanism renewing deep water in the central Baltic Sea (Matthäus et al., 2008). A major Baltic inflow (MBI) occurred in 2014-2015 (Mohrholz et al., 2015); this event ventilated bottom waters for 5 months between February and July 2015 (Holtermann et al., 2017). This MBI caused the intrusion of $\mathrm{O}_{2}$ to deep hypoxic waters, substantial temperature variability (Holtermann et al., 2017), displacement of remnant stagnant water masses by new water that changed the chemistry of the water column (Myllykangas et al., 2017), and high turbidities that may be associated with redox reactions products (Schmale et al., 2016). At the time of sampling (June 2015), the MBI had reached GB but did not affect $L D$, located further northwest. The oxygenated water inflow reached GB at the beginning of March and created a secondary near-bottom redoxcline (Schmale et al., 2016); the bottom-water anoxia started to reestablish in July 2015 (Dellwig et al., 2018). In LD, water properties did not change due to the MBI, the sulfidic layer was maintained (hydrogen sulfide, $\mathrm{H}_{2} \mathrm{~S}$ concentrations of $20.7-21.2 \mu \mathrm{M}$ ), and salinity varied between 10.6 and 10.9 (Holtermann et al., 2017).

Pelagic redoxclines are the suboxic transition between oxic and anoxic - even sulfidic - waters. A steep redox gradient characterizes this transition zone where electron acceptors and their reduced counterparts are vertically segregated, and biogeochemical transformations mediated by microbial processes are actively occurring (Bonaglia et al., 2016; Brettar and Rheinheimer, 1991; Neretin et al., 2003). For in- 
stance, iron $(\mathrm{Fe})$ and manganese $(\mathrm{Mn})$ undergo rapidly reversible transformations at the redox interface. $\mathrm{Mn}$ is an essential electron donor and acceptor in redox processes occurring in brackish, pelagic systems with anoxic conditions like the deep basins of the Baltic Sea. Redox conditions control the biogeochemical transformations between dissolved $\mathrm{Mn}^{2+}$ and insoluble oxides and hydroxides of $\mathrm{Mn}^{4+}$. Under anoxic conditions dissolved and reduced $\mathrm{Mn}$ forms dominate, while in the presence of $\mathrm{O}_{2}$ the formation of particulate manganese oxides $(\mathrm{MnOx})$ is favored. The concentration of dissolved Mn may reach $0.3 \mu \mathrm{M}$ in GB and a maximum value of about $3 \mu \mathrm{M}$ in the LD (Dellwig et al., 2012). Van Hulten et al. (2017) estimated an aggregation threshold for manganese oxides of $25 \mathrm{pM}$ and suggested that a minimal concentration of dissolved $\mathrm{Mn}$ is required for an efficient aggregation and removal of MnOx. Therefore, in GB and $\mathrm{LD}$, the balance between dissolve $\mathrm{Mn}$ and the formation of $\mathrm{MnOx}$ is controlled by the $\mathrm{O}_{2}$ availability (e.g., Neretin et al., 2003). LD is characterized by a permanently stratified water column and sulfidic bottom waters; these conditions favored the accumulation of high concentrations of dissolved Mn (Dellwig et al., 2012).

In contrast, GB is periodically affected by lateral intrusions of $\mathrm{O}_{2}$ and the oxygenation of deep water as a result of MBIs that occur every 1 to 4 years (Matthäus and Franck, 1992), favoring the occurrence of MnOx-containing particles. MnOx production may be microbially mediated (Richardson et al., 1988) or authigenic (Glockzin et al., 2014). In sulfidic waters, the reduction of $\mathrm{MnOx}$ with sulfide occurs within a scale of seconds to minutes (Neretin et al., 2003) and is inhibited by nitrate (Dollhopf et al., 2000). The oxygenation of the deep water of GB by the 2014-2015 MBI combined with the release of $\mathrm{Mn}$ from the sediments into the water column (Lenz et al., 2015) generated appropriate conditions to enhance particulate $\mathrm{MnOx}$ formation and vertically expand the zone where they could be observed in the water column.

MnOx-containing particles have previously been observed at pelagic redoxclines in the Baltic Sea (Glockzin et al., 2014; Neretin et al., 2003). They are amorphous or star-shaped particles and occur as single particles or form aggregates with OM (Neretin et al., 2003), specifically with transparent exopolymer particles (TEPs) (Glockzin et al., 2014). The sinking velocity $\left(0.76 \mathrm{~m} \mathrm{~d}^{-1}\right)$ of those mixed aggregates containing MnOx and TEPs was lower than what was predicted by the Stokes law, possibly due to their star-shaped morphology and the high OM content. TEPs are highly sticky, polysaccharide-rich particles that can enhance particle aggregation rates and the formation of marine snow (Engel, 2000; Logan et al., 1995). Thus, the sinking of MnOx-OM aggregates may contribute to the downward flux of POC. However, high content of TEPs relative to more dense particles could reduce the density of marine aggregates and decrease their sinking velocity (Engel and Schartau, 1999). Another type of less studied exopolymer particles are CSPs; they are protein- containing particles that stain with Coomassie brilliant blue (Long and Azam, 1996). Little is known about the characteristics and dynamics of those particles in marine systems, and their potential to form aggregates with $\mathrm{MnOx}$ has not been studied. Different to TEPs, CSPs have a limited role in the aggregation of diatoms (Prieto et al., 2002; Cisternas-Novoa et al., 2015), but seem to be important for the aggregation of cyanobacteria (Cisternas-Novoa et al., 2015). Mixed MnOxOM aggregates may affect the cycling of particle-reactive elements like phosphorus and trace metals via scavenging processes, and it has been proposed that they could act as carriers of bacteria in the redoxcline (Dellwig et al., 2010). To date, there are no measurements of the density of $\mathrm{MnOx}-\mathrm{OM}$ aggregates, their potential ballast effect on sinking OM, or their biogeochemical role modifying the vertical flux of POM in the Baltic Sea.

The objectives of this study are, first, to determine the amount and composition of particles sinking out of the euphotic zone into the deep basins of the Baltic Sea: GB and LD. The second objective is to study how the oxygenation of deep waters $(>140 \mathrm{~m})$ caused by the 2014-2015 MBI may affect the vertical flux of sinking particles. We therefore compared GB, which was affected by the MBI, with LD, which was not affected and exhibited low $\mathrm{O}_{2}$ concentration $(>74 \mathrm{~m})$ and even sulfidic conditions $(>180 \mathrm{~m})$. We hypothesized that the MBI that altered the water column chemistry and created different $\mathrm{O}_{2}$ conditions in $\mathrm{GB}$ compared with $\mathrm{LD}$ affected the composition and vertical flux of sinking particles. Additionally, the higher abundance and in situ formation of $\mathrm{MnOx}-$ OM aggregates may cause differences in the degradation and export of OM between the two basins.

\section{Methods}

\subsection{Sampling location and water column properties}

Samples were collected during the BalticOM cruise in the Baltic Sea onboard the RV Alkor form 3 to 19 June 2015. We collected sinking particles using surface-tethered drifting sediment traps (Engel et al., 2017; Knauer et al., 1979) in GB and LD (Table 1). Additionally, water column samples (Table 2) were collected using a Niskin-bottle rosette at the locations of the trap deployments. Temperature, salinity and $\mathrm{O}_{2}$ concentration were determined at each station using a SeaBird (CTD) probe equipped with an $\mathrm{O}_{2}$ sensor (Oxyguard, PreSens), calibrated with discrete samples measured using the Winkler method (Strickland and Parsons, 1968; Wilhelm, 1888).

\subsection{Sediment trap design and deployment}

We deployed two surface-tethered drifting sediment traps for 2 days in GB and 1 day in LD (Fig. 1). Each trap collected particles at four depths: $40 \mathrm{~m}$ (two arrays were deployed to evaluate replicability of particle collection), $60 \mathrm{~m}$ (55 m in 
Table 1. Sediment trap deployment and recovery locations, dates, collection times and depths. Two sediment traps were deployed at $40 \mathrm{~m}$ (A and $\mathrm{B}$ ) to evaluate replicability.

\begin{tabular}{lllllrl}
\hline Station & Lat. & Long. & Date & $\begin{array}{l}\text { Station } \\
\text { depth }\end{array}$ & $\begin{array}{c}\text { Deployment } \\
\text { time }(\mathrm{d})\end{array}$ & $\begin{array}{l}\text { Trap depths } \\
(\mathrm{m})\end{array}$ \\
\hline $\begin{array}{l}\text { Gotland Basin } \\
\text { (GB) }\end{array}$ & $\begin{array}{l}57.21^{\circ} \mathrm{N} \\
57.27^{\circ} \mathrm{N}\end{array}$ & $20.03^{\circ} \mathrm{E}$ & $\begin{array}{l}8 \text { June } 2015 \\
\text { 10 June } 2015\end{array}$ & $248 \mathrm{~m}$ & 2 & $\begin{array}{l}40 \mathrm{~A}, 40 \mathrm{~B}, 60, \\
110, \text { and } 180 \mathrm{~m}\end{array}$ \\
\hline Landsort Deep & $58.69^{\circ} \mathrm{N}$ & $18.55^{\circ} \mathrm{E}$ & 15 June 2015 & $460 \mathrm{~m}$ & 1 & $40 \mathrm{~A}, 40 \mathrm{~B}, 55$, \\
$(\mathrm{LD})$ & $58.68^{\circ} \mathrm{N}$ & $18.68^{\circ} \mathrm{E}$ & 16 June 2015 & & & 110, and $180 \mathrm{~m}$ \\
\hline
\end{tabular}

Table 2. Abundance of chlorophyll- and phycoerythrin-containing picoplankton and nanoplankton measured by flow cytometry in GB and LD.

\begin{tabular}{|c|c|c|c|c|c|c|c|}
\hline & \multirow[b]{2}{*}{ Depth (m) } & \multicolumn{3}{|c|}{ Phytoplankton (cells $\mathrm{mL}^{-1}$ ) } & \multicolumn{3}{|c|}{ Cyanobacteria-like (cells $\mathrm{mL}^{-1}$ ) } \\
\hline & & Picoplankton & Nanoplankton & Total & Picoplankton & Nanoplankton & Total \\
\hline \multirow[t]{9}{*}{ GB } & 1 & 87963 & 2097 & 90060 & 5225 & 731 & 5956 \\
\hline & 10 & 94369 & 2628 & 96997 & 8795 & 920 & 9716 \\
\hline & 40 & 4999 & 68 & 5067 & 2174 & 69 & 2243 \\
\hline & 60 & 4125 & 35 & 4160 & 1990 & 42 & 2032 \\
\hline & 80 & 599 & 7 & 606 & 238 & 15 & 253 \\
\hline & 110 & 594 & 7 & 601 & 326 & 29 & 356 \\
\hline & 140 & 1144 & 14 & 1158 & 356 & 2 & 358 \\
\hline & 180 & 908 & 9 & 917 & 366 & 20 & 385 \\
\hline & 220 & 2270 & 19 & 2289 & 1063 & 34 & 1097 \\
\hline \multirow[t]{12}{*}{ LD } & 1 & 92359 & 2283 & 94642 & 834 & 177 & 1011 \\
\hline & 10 & 86426 & 1708 & 88134 & 2990 & 232 & 3223 \\
\hline & 40 & 2022 & 92 & 2114 & 2243 & 69 & 2312 \\
\hline & 60 & 1524 & 62 & 1586 & 1294 & 24 & 1318 \\
\hline & 70 & 908 & 43 & 951 & 613 & 17 & 630 \\
\hline & 110 & 1735 & 82 & 1817 & 1181 & 17 & 1198 \\
\hline & 180 & 1339 & 75 & 1415 & 946 & 34 & 980 \\
\hline & 250 & 1593 & 82 & 1676 & 949 & 36 & 985 \\
\hline & 300 & 1521 & 48 & 1569 & 1047 & 17 & 1064 \\
\hline & 350 & 1608 & 57 & 1665 & 908 & 12 & 920 \\
\hline & 400 & 1548 & 73 & 1621 & 1047 & 22 & 1069 \\
\hline & 430 & 1562 & 68 & 1631 & 875 & 19 & 894 \\
\hline
\end{tabular}

LD), $110 \mathrm{~m}$ and $180 \mathrm{~m}$ (Table 1) to estimate POM fluxes to and within the OMZ. $40 \mathrm{~m}$ was considered as the base of the euphotic zone based on photosynthetically active radiation measurements conducted during the cruise (data not shown). At each depth, 12 acrylic particle interceptor tubes (PITs) mounted in a PVC cross-frame were deployed. Each PIT was equipped with an acrylic baffle at the top to minimize the collection of swimmers (Engel et al., 2017; Knauer et al., 1979). The PITs were $7 \mathrm{~cm}$ in diameter and $53 \mathrm{~cm}$ in height with an aspect ratio of 7.5 and a collection area of $0.0038 \mathrm{~m}^{-2}$. The cross-frame and PITs were attached to a line that had a bottom weight and a set of surface and subsurface floats. The procedures for PIT preparation and sample recovery followed Engel et al. (2017). Shortly before deployment, each PIT was filled with $1.5 \mathrm{~L}$ of seawater previously filtered through a $0.2 \mu \mathrm{m}$ pore size cartridge. A preser- vative solution of saline brine $\left(50 \mathrm{~g} \mathrm{~L}^{-1}\right)$ was added slowly to each PIT underneath the $1.5 \mathrm{~L}$ of filtered seawater, carefully keeping the density gradient. The PITs were kept covered until deployment and immediately after recovery to avoid contamination. After recovery, the density gradient was visually verified, and the supernatant seawater was siphoned off the PIT. Then, we pooled together the remaining water, containing the sinking material $(\sim 0.6-0.8 \mathrm{~L})$, of 12 tubes per depth into a large container that we filled up to $10 \mathrm{~L}$ with filtered seawater (between 0.4 and $1.5 \mathrm{~L}$ ) to have the same volume per depth. After that, the samples were screened with a $500 \mu \mathrm{m}$ mesh to remove swimmers (Conte et al., 2001). Subsequently, samples were split into aliquots that were processed for the different biogeochemical analysis as described in Engel et al. (2017). 


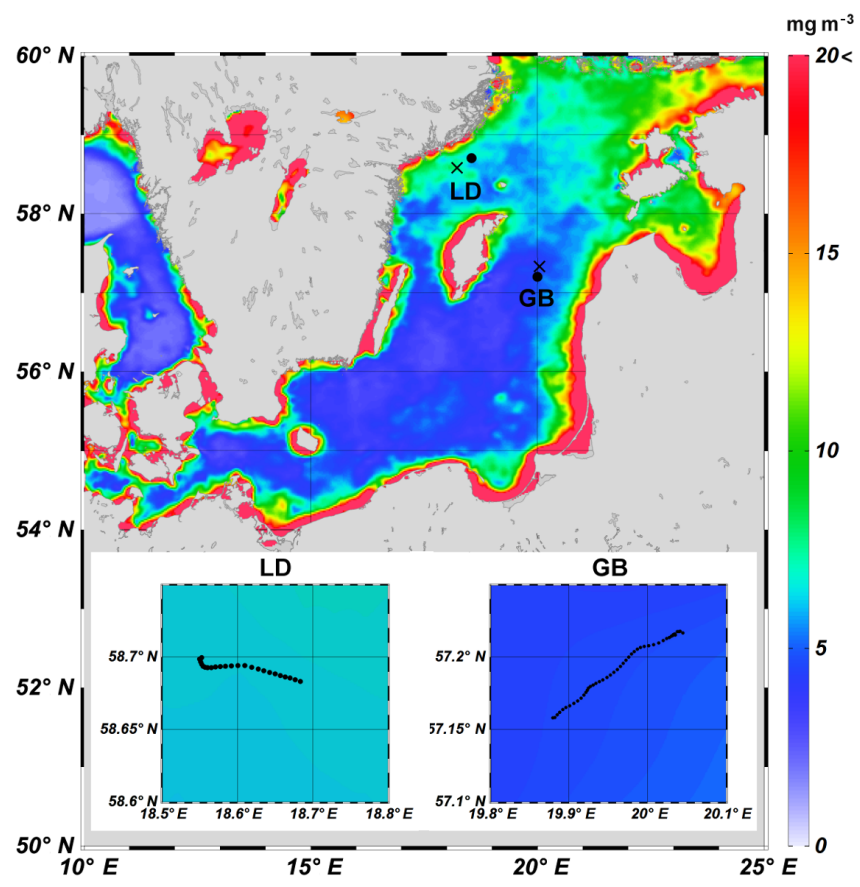

Figure 1. Monthly averaged Chl $a$ distribution derived from VIIRS for June 2015 in the Baltic Sea. Black circle and " $x$ " indicate the position of the trap deployment and the seawater collection, respectively, in Gotland Basin (GB) and Landsort Deep (LD). The lower panel shows the trajectory of the trap deployed at GB and LD.

\subsection{Biogeochemical analysis}

Nutrients were measured in seawater samples collected at the deployment stations. Ammonium (detection limit of $0.05 \mu \mathrm{M})$ was measured directly on unfiltered seawater samples onboard after Solórzano (1969). Phosphate, nitrate and nitrite (detection limit of $0.04 \mu \mathrm{M}$ ) were filtered through a $0.2 \mu \mathrm{m}$ pore size and stored frozen until their analysis; samples were measured photometrically with continuous-flow analysis on an auto-analyzer (QuAAtro; Seal Analytical) after Grasshoff et al. (1999).

Particulate organic carbon (POC), nitrogen (PN), organic phosphorus (POP) and chlorophyll $a(\mathrm{Chl} a$ ) were determined as described in Engel et al. (2017). Aliquots of 100 to $200 \mathrm{~mL}$ of the trapped material and $500 \mathrm{~mL}$ of the seawater samples were filtered in duplicate for each parameter at low vacuum $(<200 \mathrm{mbar}$ ) onto precombusted $\mathrm{GF} / \mathrm{F}$ filters $\left(8 \mathrm{~h}\right.$ at $\left.500^{\circ} \mathrm{C}\right)$. The filters were stored frozen $\left(-20^{\circ} \mathrm{C}\right)$ until analysis. Prior to analysis, filters for POC-PN determination were exposed to acid fumes ( $37 \%$ hydrochloric acid) to remove carbonates and subsequently dried for $12 \mathrm{~h}$ at $60^{\circ} \mathrm{C}$. $\mathrm{POC}$ and PN concentrations were determined using an elemental analyzer (Euro EA, Hechatech) after Sharp (1974).

POP was analyzed after Hansen and Koroleff (1999). POP was oxidized to orthophosphate by heating the filters in $40 \mathrm{~mL}$ of deionized water (18.2 M $\Omega$ ) with Oxisolv (Merck
112936 ) for $30 \mathrm{~min}$ in a pressure cooker. Orthophosphate was determined spectrophotometrically at $882 \mathrm{~nm}$ in a Shimadzu UV-Vis spectrophotometer UV1201.

Chl $a$ was analyzed after extraction with $10 \mathrm{~mL}$ of $90 \%$ acetone, and the fluorescence of the samples was measured using a Turner fluorometer (excitation $440 \mathrm{~nm}$, emission $685 \mathrm{~nm}$; Turner 10AU) according to Strickland et al. (1972). The fluorometer was calibrated with a standard solution of Chl $a$ (Sigma-Aldrich C-5753).

Biogenic silica (BSi) was determined in aliquots of 50 to $100 \mathrm{~mL}$, filtered in duplicate onto $0.4 \mu \mathrm{m}$ cellulose acetate filters. Samples were stored at $-20^{\circ} \mathrm{C}$ until analysis. For the measurements, filters were digested in $\mathrm{NaOH}$ at $85^{\circ} \mathrm{C}$ for $135 \mathrm{~min}$; the $\mathrm{pH}$ was adjusted to 8 with $\mathrm{HCl}$. Silicate was measured spectrophotometrically according to Hansen and Koroleff (2007).

Polysaccharide (TEP) and protein (CSP) exopolymer particles, from sediment trap and water column samples, were analyzed by microscopy according to Engel (2009). Duplicate aliquots of 5 to $20 \mathrm{~mL}$ were filtered onto $0.4 \mu \mathrm{m}$ Nuclepore membrane filters (Whatmann) and stained with $1 \mathrm{~mL}$ of Alcian blue solution, a dye that targets acidic polysaccharides, for TEPs or $1 \mathrm{~mL}$ of Coomassie brilliant blue solution, a dye commonly used to stain proteins (Bradford, 1976), for CSPs. Filters were transferred onto Cytoclear ${ }^{\circledR}$ slides and frozen $\left(-20^{\circ} \mathrm{C}\right)$ until microscopy analysis. For the analysis, 30 images for each filter were captured under $200 \times$ magnification using a light microscope (Zeiss Axio Scope.A1) connected to a color camera (AxioCam MRc). Particle abundance and area were measured semiautomatically using an image analysis system including the WCIF ImageJ software. The RGB was split into three channels (red, blue and green), and the red was used to quantify the amount of TEPs and CSPs. Additionally, TEPs and CSPs in water samples from the stations where we deployed sediment traps were analyzed spectrophotometrically (with higher vertical resolution than microscopy) according to Passow and Alldredge (1995) and Cisternas-Novoa et al. (2014), respectively. Concentrations of TEPs are reported relative to a xanthan gum standard and expressed in micrograms of xanthan gum equivalent per liter ( $\mu \mathrm{g}$ XG eq. $\mathrm{L}^{-1}$ ), and concentrations of CSPs are reported relative to a bovine serum albumin standard and expressed in micrograms of bovine serum albumin equivalent per liter ( $\mu \mathrm{g}$ BSA eq. $\mathrm{L}^{-1}$ ).

MnOx-containing particles have been commonly identified based on their morphology, size and elemental composition, confirmed by scanning electron microscopy (SEM) and energy-dispersive X-ray microanalysis (EDX) (Neretin et al., 2003; Glockzin et al., 2014; Dellwig et al., 2010, 2018). In this study, we did not measure the elemental composition of the particles. Thus, we identified them as MnOx-like particles based on similar morphology, size and association with organic matter (OM) as MnOx-containing particles previously described in the Baltic Sea (eg., Neretin et al., 2003; Glockzin et al., 2014). The abundance and size of MnOx-like 
particles were determined using particle recognition on filters and image processing similar to the method used by Neretin et al. (2003) but without the chemical composition analysis of the particles. For the image analysis, we used the same images as for TEP and CSP analysis and modified the image analysis procedure described above as follows: 30 images per filter $(200 \times)$ were analyzed semiautomatically using Image J software. After RGB split, the blue channel pictures were used to quantify MnOx-like particles in the water column and sediment traps. In this manner, the MnOx-like particles were clearly visible with a negligible disruption from TEPs or CSPs stained blue.

Total hydrolyzable amino acids (TAAs) were analyzed in unfiltered seawater and trapped material. Samples were stored at $-20{ }^{\circ} \mathrm{C}$ until analysis. Duplicate samples were hydrolyzed at $100^{\circ} \mathrm{C}$ in $6 \mathrm{~N} \mathrm{HCl}$ (Suprapur ${ }^{\circledR}$ hydrochloric acid $30 \%$ ) and $11 \mathrm{mM}$ ascorbic acid for $20 \mathrm{~h}$. Amino acids were separated and measured by high-performance liquid chromatography (HPLC), after derivatization with orthophthaldialdehyde using a fluorescence detector (excitation $330 \mathrm{~nm}$, emission $445 \mathrm{~nm}$ ) (Dittmar et al., 2009; Lindroth and Mopper, 1979). TAA concentrations were reported as $\mu \mathrm{M}$ of monomer. The quantitative degradation index (DI) of Dauwe et al. (1999), based on changes in the amino acid composition of POM as it undergoes degradation processes, was calculated using the factor coefficient of Dauwe et al. (1999) and the average and standard deviation of the TAAs in this data set.

Total combined carbohydrates (TCHOs) $>1 \mathrm{kDa}$ were determined by HPAEC-PAD according to Engel and Händel (2011). TCHOs were analyzed in the unfiltered seawater and sediment trap material. Samples were stored at $-20^{\circ} \mathrm{C}$ until analysis. Prior to analysis, the samples were desalted by membrane dialysis using dialysis tubes with a $1 \mathrm{kDa}$ molecular weight cutoff (Spectra Por). Desalination was conducted for $4.5 \mathrm{~h}$ at $1{ }^{\circ} \mathrm{C}$. Then, a $2 \mathrm{~mL}$ subsample was sealed with $1.6 \mathrm{~mL}$ of $1 \mathrm{M} \mathrm{HCl}$ in precombusted glass ampoules and hydrolyzed for $20 \mathrm{~h}$ at $100^{\circ} \mathrm{C}$. After hydrolysis, the subsamples were neutralized by acid evaporation under $\mathrm{N}_{2}$ atmosphere at $50^{\circ} \mathrm{C}$, resuspended with ultrapure Milli-Q water and analyzed on a Dionex 3000 ion chromatography system. TCHO concentrations were reported as $\mu \mathrm{M}$ of monomer.

\subsection{Phytoplankton abundance}

Phytoplankton composition and abundance at the stations where we deployed sediment traps were evaluated using light microscopy and flow cytometry. Counts of phytoplankton cells $>5 \mu \mathrm{m}$ were made from $50 \mathrm{~mL}$ of fixed samples (Lugol's solution, $1 \%$ final concentration). Samples were concentrated using gravitational settling and counted under a Zeiss Axiovert inverted microscope (200× magnification) following the guidelines for determination of phytoplankton species composition and abundance (HELCOM, 2012). The counts were made on either half (cyanobacteria, diatoms and
Dinophysis sp.) or two strips (Cryptophyta, unidentified dinoflagellates and Chlorophyta) of the chamber. Individual filaments of cyanobacteria were counted in $50 \mu \mathrm{m}$ length units. The size of the counted phytoplankton species ranged from 10 to $200 \mu \mathrm{m}$.

Phytoplankton, $<20 \mu \mathrm{m}$, cell abundance was quantified using a flow cytometer (FACSCalibur, Becton Dickinson, Oxford, UK). $2 \mathrm{~mL}$ samples were fixed with formaldehyde ( $1 \%$ final concentration) and stored frozen $\left(-80^{\circ} \mathrm{C}\right)$ until analysis ( 2 weeks later). Red and orange autofluorescence was used to identify chlorophyll and phycoerythrin cells. Cell counts were determined with CellQuest software (Becton Dickinson); picoplankton and nanoplankton populations of naturally containing chlorophyll and/or phycoerythrin (i.e., Synechococcus) were identified and enumerated.

\subsection{Statistics}

Significant differences between two parameters were tested using the Mann-Whitney $U$ test. The results of statistical analyses were assumed to be significant at $p$ values $<0.05$. Statistical analyses were performed using MATLAB software (MatlabR2014a).

\section{Results}

\subsection{Biogeochemistry of the water column}

At both stations, GB and LD, the water column was stratified during the study. In GB, the seasonal thermocline was located between 22 and $37 \mathrm{~m}$, with temperature decreasing rapidly from $9.8^{\circ} \mathrm{C}$ in the surface mixed layer to $4.7^{\circ} \mathrm{C}$ below $37 \mathrm{~m}$ (Fig. 2a). Deeper in the water column, a pycnocline (halocline) coincided with the oxycline and was located between $65 \mathrm{~m}(S=7.6)$ and $80 \mathrm{~m}(S=10.2)$; below $80 \mathrm{~m}$ the salinity gradually increased up to $13.5(220 \mathrm{~m})$. A hypoxic layer $\left(<40 \mu \mathrm{M} \mathrm{O}_{2}\right)$ was located between 74 and $140 \mathrm{~m}$; the core of the OMZ $\left(<10 \mu \mathrm{M} \mathrm{O}_{2}\right)$ was located between 96 and $125 \mathrm{~m}$. The $\mathrm{O}_{2}$ concentration increased from $35 \mu \mathrm{MO}_{2}$ at $140 \mathrm{~m}$ to $79 \mu \mathrm{MO}_{2}$ at $220 \mathrm{~m}$ (Fig. 2a). In LD, the seasonal thermocline was located between 10 and $39 \mathrm{~m}$, where the temperature decreased gradually from 12 to $4.0^{\circ} \mathrm{C}$ (Fig. 2b). The pycnocline was between $55(S=7.2)$ and $75 \mathrm{~m}(S=9)$; below that the salinity was constant $(S=10.7)$ until the bottom of the station $(430 \mathrm{~m})$. The $\mathrm{O}_{2}$ concentration was below the detection limit $\left(<3 \mu \mathrm{MO}_{2}\right)$ from $74 \mathrm{~m}$ to the deepest point sampled in LD $(430 \mathrm{~m})$.

The vertical profile of nutrients was different at both stations (Fig. 2). In GB, nitrate concentration increased from below the detection limit in the upper $10 \mathrm{~m}$ to $0.17 \mu \mathrm{M}$ at $40 \mathrm{~m}$ (Fig. 2a). Concentrations were variable within the $\mathrm{OMZ}$ with $6 \mu \mathrm{M}$ in the upper $(80 \mathrm{~m})$ and lower oxycline $(140 \mathrm{~m})$ and $0.12 \mu \mathrm{M}$ in the core of the OMZ $(110 \mathrm{~m})$. The nitrate concentration was $4.8 \mu \mathrm{M}$ in the deepest sample $(220 \mathrm{~m})$. Nitrite was below the detection limit in most of the water column 
(a) Temperature $\left({ }^{\circ} \mathrm{C}\right) \quad \mathrm{NO}_{3} / \mathrm{NH}_{4}(\mu \mathrm{M})$

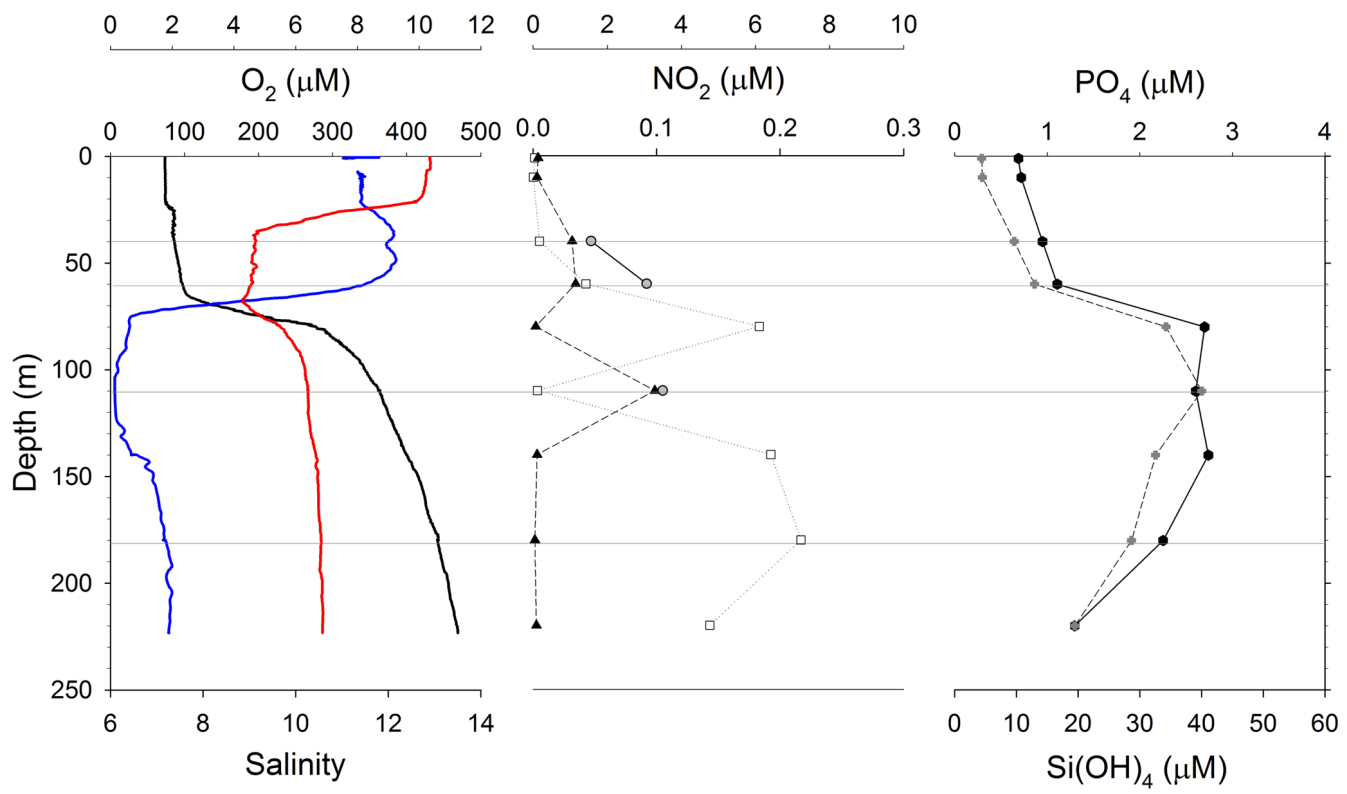

(b) Temperature $\left({ }^{\circ} \mathrm{C}\right)$
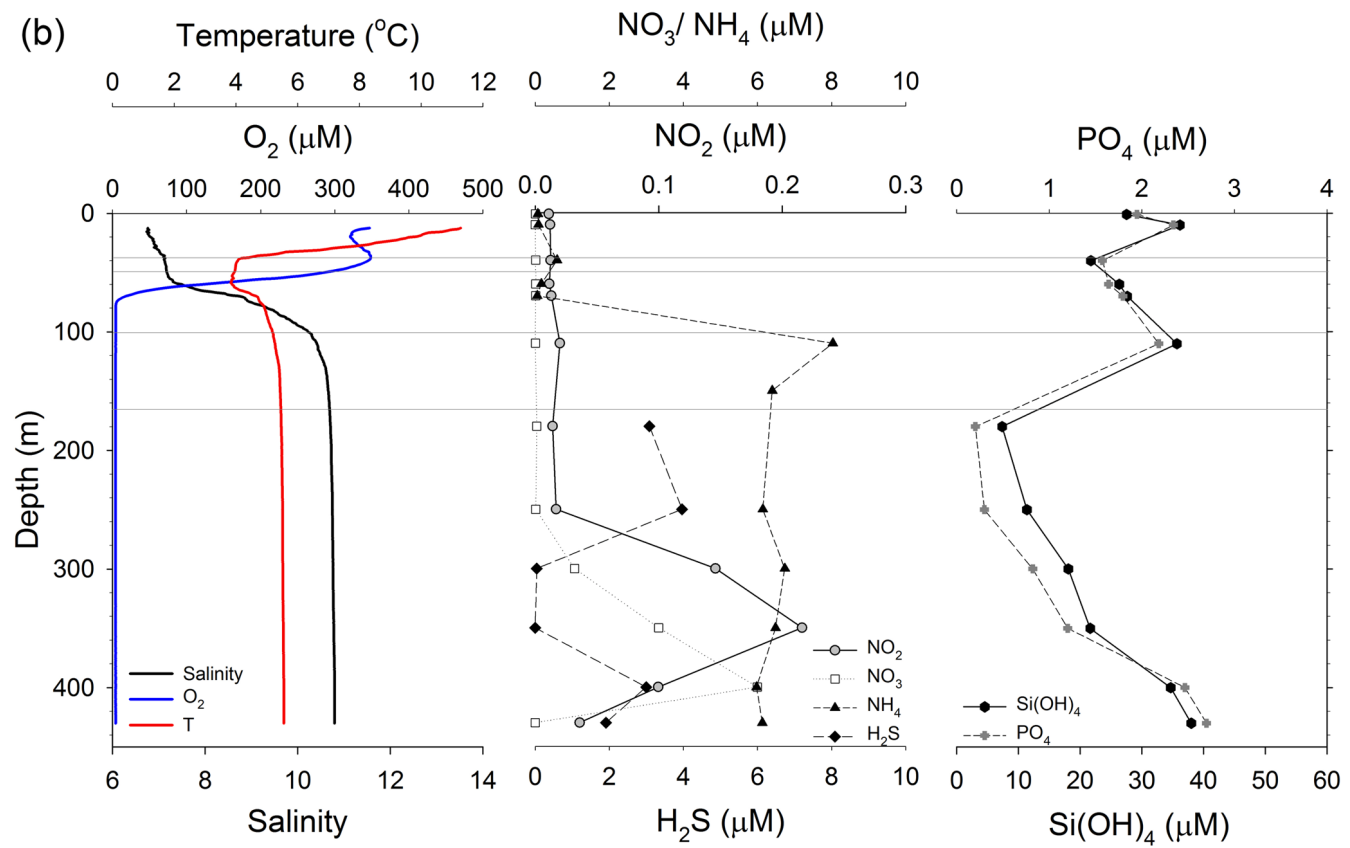

Figure 2. Water column profiles at the location of the sediment trap deployments in (a) GB, and (b) LD. Left panels: oxygen (blue), temperature (red) and salinity (black). Middle panels: nitrate $\left(\mathrm{NO}_{3}\right.$, white squares), nitrite $\left(\mathrm{NO}_{2}\right.$, grey circles), ammonium $\left(\mathrm{NH}_{4}\right.$, black triangles) and hydrogen sulfide $\left(\mathrm{H}_{2} \mathrm{~S}\right.$, black diamonds). Right panels: phosphate $\left(\mathrm{PO}_{4}\right.$, grey diamond) and silicate $\left(\mathrm{Si}(\mathrm{OH})_{4}\right.$, black circles) Grey lines indicate the depths at which we deployed sediment traps.

except for $60 \mathrm{~m}(0.09 \mu \mathrm{M})$ and $110 \mathrm{~m}(0.11 \mu \mathrm{M})$. Ammonium increased from $0.14 \mu \mathrm{M}$ in the upper $10 \mathrm{~m}$ to $1.15 \mu \mathrm{M}$ at $40 \mathrm{~m}$; concentrations were variable within the OMZ with less than $0.15 \mu \mathrm{M}$ in the upper $(80 \mathrm{~m})$ and lower oxycline $(140 \mathrm{~m})$ and a maximum concentration of $3.28 \mu \mathrm{M}$ in the core of the $\mathrm{OMZ}$ $(110 \mathrm{~m})$. Vertical profiles of phosphate and silicate at GB were similar; the concentrations steadily increased from the upper $10 \mathrm{~m}$ of the water column $(0.29$ and $10.36 \mu \mathrm{M}$, respectively) to the OMZ (2.67 and $39.07 \mu \mathrm{M}$, respectively) and gradually decreased below the OMZ (Fig. 2a). $\mathrm{H}_{2} \mathrm{~S}$ was not detectable in GB.

In $\mathrm{LD}$, nitrate and nitrite concentrations were below the detection limit between the surface and $250 \mathrm{~m}(<0.04 \mu \mathrm{M})$ (Fig. 2b). Nitrite showed a maximum of $0.22 \mu \mathrm{M}$ at $350 \mathrm{~m}$, 
Table 3. Phytoplankton abundance analyzed microscopically for samples collected at the location of trap deployment in GB and LD.

\begin{tabular}{|c|c|c|c|c|c|c|c|c|c|}
\hline & & \multicolumn{8}{|c|}{ Phytoplankton abundance $\left(\mathrm{L}^{-1}\right)$} \\
\hline & & \multicolumn{4}{|c|}{ GB } & \multicolumn{4}{|c|}{ LD } \\
\hline & & $1 \mathrm{~m}$ & $10 \mathrm{~m}$ & $40 \mathrm{~m}$ & Total & $1 \mathrm{~m}$ & $10 \mathrm{~m}$ & $40 \mathrm{~m}$ & Total \\
\hline Cyanobacteria* & Total & 14148 & 13536 & 0 & 27684 & 37368 & 32526 & 96 & 69990 \\
\hline Cryptophyta & Total & 140 & 112 & 28 & 280 & 1400 & 882 & 56 & 2338 \\
\hline \multirow[t]{4}{*}{ Bacillariophyceae } & Total & 96 & 94 & 44 & 234 & 462 & 112 & 102 & 676 \\
\hline & Chaetoceros sp. & 58 & 42 & 24 & 124 & 434 & 106 & 26 & 566 \\
\hline & Skeletonema sp. & 26 & 8 & 12 & 46 & 12 & 0 & 8 & 20 \\
\hline & Thalassiosira sp. & 12 & 44 & 8 & 64 & 16 & 6 & 68 & 90 \\
\hline \multirow[t]{3}{*}{ Dinophyceae ${ }^{* *}$} & Total & 3772 & 4424 & 1192 & 9388 & 9032 & 7662 & 1404 & 18098 \\
\hline & Dinophysis sp. & 678 & 742 & 2 & 1422 & 450 & 214 & 4 & 668 \\
\hline & Other & 3094 & 3682 & 1190 & 7966 & 8582 & 7448 & 1400 & 17430 \\
\hline \multirow[t]{2}{*}{ Chlorophyta } & Total & 5320 & 6860 & 28 & 12208 & 2072 & 1022 & 238 & 3332 \\
\hline & Planctonema sp. & 5320 & 6860 & 28 & 12208 & 2072 & 1022 & 238 & 3332 \\
\hline
\end{tabular}

* Filamentous cyanobacteria were counted in $50 \mu \mathrm{m}$ length units (>90\% were Aphanizomenon sp.). ${ }^{* *}$ Includes mixotrophs.

and nitrate a maximum of $6.0 \mu \mathrm{M}$ at $400 \mathrm{~m}$. Ammonium concentrations varied between 0.06 and $0.59 \mu \mathrm{M}$ in the upper $70 \mathrm{~m}$ and increased to 5.97 and $8.03 \mu \mathrm{M}$ in the $\mathrm{OMZ}$ $(>74 \mathrm{~m})$. The lowest ammonium concentration $(0.07 \mu \mathrm{M})$ was measured in the surface and the highest $(8.03 \mu \mathrm{M})$ at $110 \mathrm{~m}$. Phosphate and silicate concentrations were relatively low within the mixed layer, gradually increased below the pycnocline, and decreased again between 110 and $180 \mathrm{~m}$. Phosphate concentrations varied between 1.5 and $2.5 \mu \mathrm{M}$ in the upper $110 \mathrm{~m}$ of the water column, decreased to $0.22 \mu \mathrm{M}$ at $180 \mathrm{~m}$ and increased to $2.7 \mu \mathrm{M}$ at $430 \mathrm{~m}$ (deepest sample). Silicate ranged between 25 and $38 \mu \mathrm{M}$ in the upper $110 \mathrm{~m}$ of the water column, decreased to $7.4 \mu \mathrm{M}$ at $180 \mathrm{~m}$, and increased to $38.9 \mu \mathrm{M}$ at $430 \mathrm{~m} . \mathrm{H}_{2} \mathrm{~S}$ was detectable below $180 \mathrm{~m}$, with the highest concentration $(3.97 \mu \mathrm{M})$ at $250 \mathrm{~m}$ and the lowest $(0.04 \mu \mathrm{M})$ between 300 and $350 \mathrm{~m}$ (Fig. 2b).

\subsection{Particulate organic matter concentration in the water column}

Chl $a$ concentration in the upper $10 \mathrm{~m}$ was slightly higher in GB (1.5-1.7 $\mu \mathrm{g} \mathrm{L}^{-1}$; Fig. 3b) than in LD (1.4-1.2 $\mu \mathrm{g} \mathrm{L}^{-1}$; Fig. 3e). At both stations, more than $90 \%$ of the total smaller phytoplankton $(<20 \mu \mathrm{m}$, picophytoplankton and nanophytoplankton) abundance, determined by flow cytometry, was measured in the upper $60 \mathrm{~m}$, although phytoplankton was detectable in the entire water column. Picophytoplankton and nanophytoplankton abundances were $10 \%$ higher in GB than in LD (Table 2). Picocyanobacteria determined by phycoerythrin fluorescence accounted for $92 \%$ and $96 \%$ of the total picophytoplankton abundance in GB and LD, respectively. Picocyanobacteria abundance was $30 \%$ higher in GB than in LD.

Phytoplankton $(>5 \mu \mathrm{m})$ abundance, determined by microscopy, was $63 \%$ higher in LD than in GB (Table 3). Fil- amentous cyanobacteria dominated the phytoplankton community at both stations with up to $90 \%$ corresponding to Aphanizomenon sp. Cyanobacteria represented $56 \%$ of the phytoplankton counts in GB and up to $74 \%$ in LD. Dinoflagellates (including mixotrophs), dominated by Dinophysis sp., were significant at both stations (19\% of the phytoplankton counts), whereas chlorophytes (dominated by filaments of Planctonema sp. containing cylindrical cells) were more abundant in GB than in LD (25\% and $4 \%$ of the phytoplankton counts, respectively). Diatoms represented less than $1 \%$ of the phytoplankton at both stations, and they were slightly more abundant at $40 \mathrm{~m}$ in LD (Table 3). BSi was higher in the upper $10 \mathrm{~m}(0.4-0.5 \mu \mathrm{M})$ and decreased with depth in GB (Fig. 3b), whereas in LD, BSi showed a peak at $40 \mathrm{~m}$ and then decreased with depth (Fig. 3e).

Vertical profiles of POC, PN and POP concentration were similar in the water column of the two stations (Fig. 3a, d). In GB, the concentrations were higher in the upper $10 \mathrm{~m}$ of the water column (POC: $40.38 \pm 0.80$, PN: $3.89 \pm 0.01$, POP: $0.26 \pm 0.04 \mu \mathrm{M})$ and decreased gradually with depth until $110 \mathrm{~m}$ where relatively high concentrations (POC: $18 \pm 0.63$, PN: $2 \pm 0.08$, POP: $0.2 \mu \mathrm{M}$ ) were observed. The lowest concentrations were found at $180 \mathrm{~m}$ (POC: $11.97 \pm 1.03$, PN: $1.05 \pm 0.02$, and POP $<0.03 \mu \mathrm{M}$ ) (Fig. $3 \mathrm{a}$ ). In LD, POM decreased with depth from the surface (POC: $35 \pm 0.99$, PN: $4 \pm 0.09$, POP: $0.2 \mu \mathrm{M}$ ) to $40 \mathrm{~m}$, remained relatively constant between 40 and $80 \mathrm{~m}$, and decreased again between 110 and $250 \mathrm{~m}$ (Fig. 3d).

We observed high concentrations of TEPs and CSPs in the upper $10 \mathrm{~m}$ at both stations. The highest TEP concentration was determined at 1 and $10 \mathrm{~m}$ at both stations, and it was slightly higher (19\%) in GB than in LD (Fig. 3c, f). TEP and CSP vertical profiles were different from each other in GB (Fig. 3c) and covaried in LD (Fig. 3f). Like observed for POC, PN and POP, TEP concentrations showed a peak 

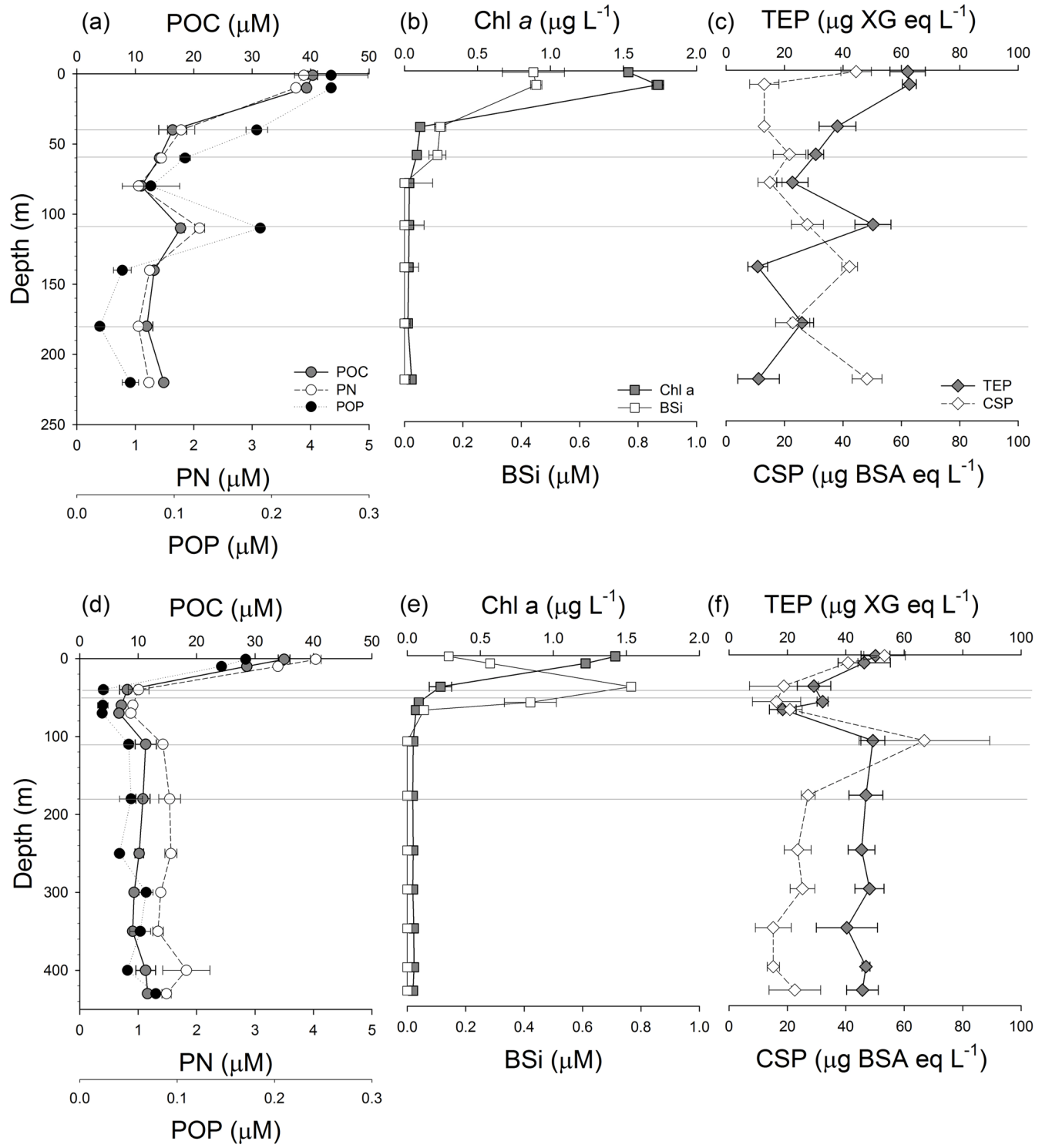

Figure 3. Vertical profiles of the concentration of particulate organic carbon (POC), particulate nitrogen (PN) and particulate organic phosphorus (POP) in GB (a) and LD (d); vertical profiles of the concentration of chlorophyll $a(\mathrm{Chl} a)$ and biogenic silicate (BSi) in GB (b) and LD (d); and vertical profiles of the concentration of transparent exopolymeric particles (TEPs) and Coomassie stainable particles (CSPs) in GB (c) and LD (f). Grey lines as Fig. 2.

at $110 \mathrm{~m}\left(50.29 \pm 6.17 \mu \mathrm{g} \mathrm{XG} \mathrm{eq.} \mathrm{L}^{-1}\right)$ in GB. The highest concentration of CSPs at this station was observed in the shallowest $(1 \mathrm{~m})$ sample; the CSP concentration decreased quickly below $10 \mathrm{~m}$, and then it increased at 140 and $220 \mathrm{~m}$ (the deepest sample, approximately $28 \mathrm{~m}$ above the seafloor) (Fig. 3c). In LD, the highest concentrations of TEPs and CSPs were measured at the surface $(1$ and $10 \mathrm{~m})$ and at $110 \mathrm{~m}$ (Fig. 3f). TEPs and CSPs decreased with depth in the first $80 \mathrm{~m}$ (from $53.26 \pm 7.10$ to $18.39 \pm 4.57 \mu \mathrm{g} \mathrm{XG} \mathrm{eq.} \mathrm{L}^{-1}$ and from $53.26 \pm 7.10$ to $31.57 \pm 18.78 \mu \mathrm{g}$ BSA eq. $\mathrm{L}^{-1}$ ). Both types of gel-like particles showed an increase in concentration at $110 \mathrm{~m}\left(49.25 \pm 4.08 \mu \mathrm{g} \mathrm{XGeq.} \mathrm{L}^{-1}\right.$ and $66.89 \pm$
$22.33 \mu \mathrm{g}$ BSA eq. $\mathrm{L}^{-1}$, respectively). Below $110 \mathrm{~m}$, TEP concentrations stayed relatively constant, while CSP concentrations decreased at $180 \mathrm{~m}$ and remained relatively constant below that depth.

\subsection{MnOx-like particle vertical distribution in the water column}

Dark, star-shaped MnOx-like particles (Glockzin et al., 2014; Neretin et al., 2003) were only observed below the fully oxygenated mixed layer in GB and, in less abundance, in LD (Fig. 4). In GB, MnOx-like particles were observed from 80 to $220 \mathrm{~m}$; they appear as single particles and forming 
(a) MnOx-like particles $\left(\mathrm{L}^{-1}\right)$

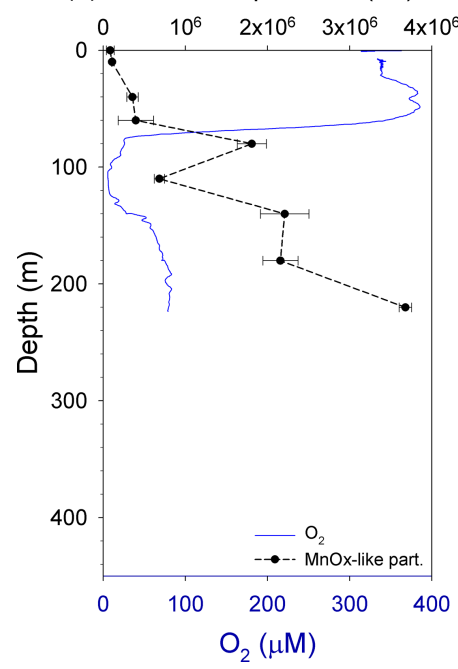

(b) $\mathrm{MnOx}$-like particles $\left(\mathrm{L}^{-1}\right)$

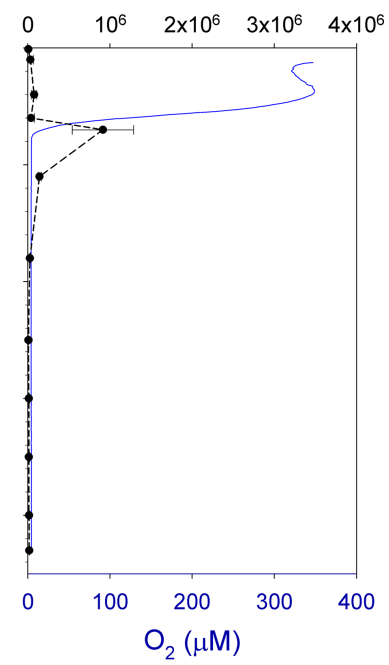

Figure 4. Vertical profiles of $\mathrm{MnOx}$-like particles and $\mathrm{O}_{2}$ concentration in the water column at the location of the sediment trap deployments. (a) GB and (b) LD. Grey lines as in Fig. 3.

large aggregates containing several MnOx-like particles associated with OM. Relatively high concentrations of MnOxlike particles $\left(2 \times 10^{6}\right.$ particles $\left.\mathrm{L}^{-1}\right)$ were observed in the upper $\left(80 \mathrm{~m}, 25 \mu \mathrm{M} \mathrm{O}_{2}\right)$ and lower $\left(140 \mathrm{~m}, 36 \mu \mathrm{M} \mathrm{O}_{2}\right)$ oxycline and at $220 \mathrm{~m}\left(79 \mu \mathrm{M} \mathrm{O}_{2} ; 4 \times 10^{6}\right.$ particles $\left.\mathrm{L}^{-1}\right)$ (Fig. $\left.4 \mathrm{a}\right)$. The lowest abundance of MnOx-like particles $\left(7 \times 10^{5}\right.$ particles $\left.\mathrm{L}^{-1}\right)$ was observed at $110 \mathrm{~m}\left(6 \mu \mathrm{MO}_{2}\right)$, i.e., in the core of the OMZ. The equivalent spherical diameter (ESD) of MnOx-like particles varied between 0.6 and $30.5 \mu \mathrm{m}$, with a median size of $3.0 \mu \mathrm{m}$. The largest aggregates (up to $30.5 \mu \mathrm{m}$ ) were observed in the upper oxycline $(80 \mathrm{~m})$. In LD, MnOxlike particles were less abundant, smaller and had a narrow distribution in the water column than in GB. MnOx-like particles were not detected in the fully oxic $(0-40 \mathrm{~m})$ or fully anoxic (180 to $430 \mathrm{~m})$ water column. At $60 \mathrm{~m}\left(135 \mu \mathrm{M} \mathrm{O}_{2}\right)$, right above the oxycline, MnOx-like particles began to appear, but in relatively low abundance. The maximum abundance of MnOx-like particles, $9 \times 10^{5} \mathrm{~L}^{-1}$, was observed in the oxycline at $70 \mathrm{~m}\left(27 \mu \mathrm{MO}_{2}\right.$, Fig. $\left.4 \mathrm{~b}\right)$. The ESD ranged between 0.6 and $13.4 \mu \mathrm{m}$, and the largest aggregates were observed at $70 \mathrm{~m}$.

\subsection{Vertical flux of sinking particles}

Vertical fluxes of POC and PN varied little with depth in GB (Fig. 5a). POC flux slightly increased by $18 \%$ from the shallowest $(40 \mathrm{~m})$ to the deepest $(180 \mathrm{~m})$ sediment trap. Fluxes of PN (Fig. 5a) and CSPs (Fig. 6b) were higher at 40 and $60 \mathrm{~m}$ and decreased (19\% and $70 \%$ ) from 60 to $180 \mathrm{~m}$, respectively. On the other hand, fluxes of POP, BSi, Chl $a$ (Fig. 5b) and TEPs (Fig. 6a) peaked in the sediment trap located in the core of the OMZ $(110 \mathrm{~m})$. The increment of fluxes at $110 \mathrm{~m}$ coincided with the high abundance of MnOx-like par-
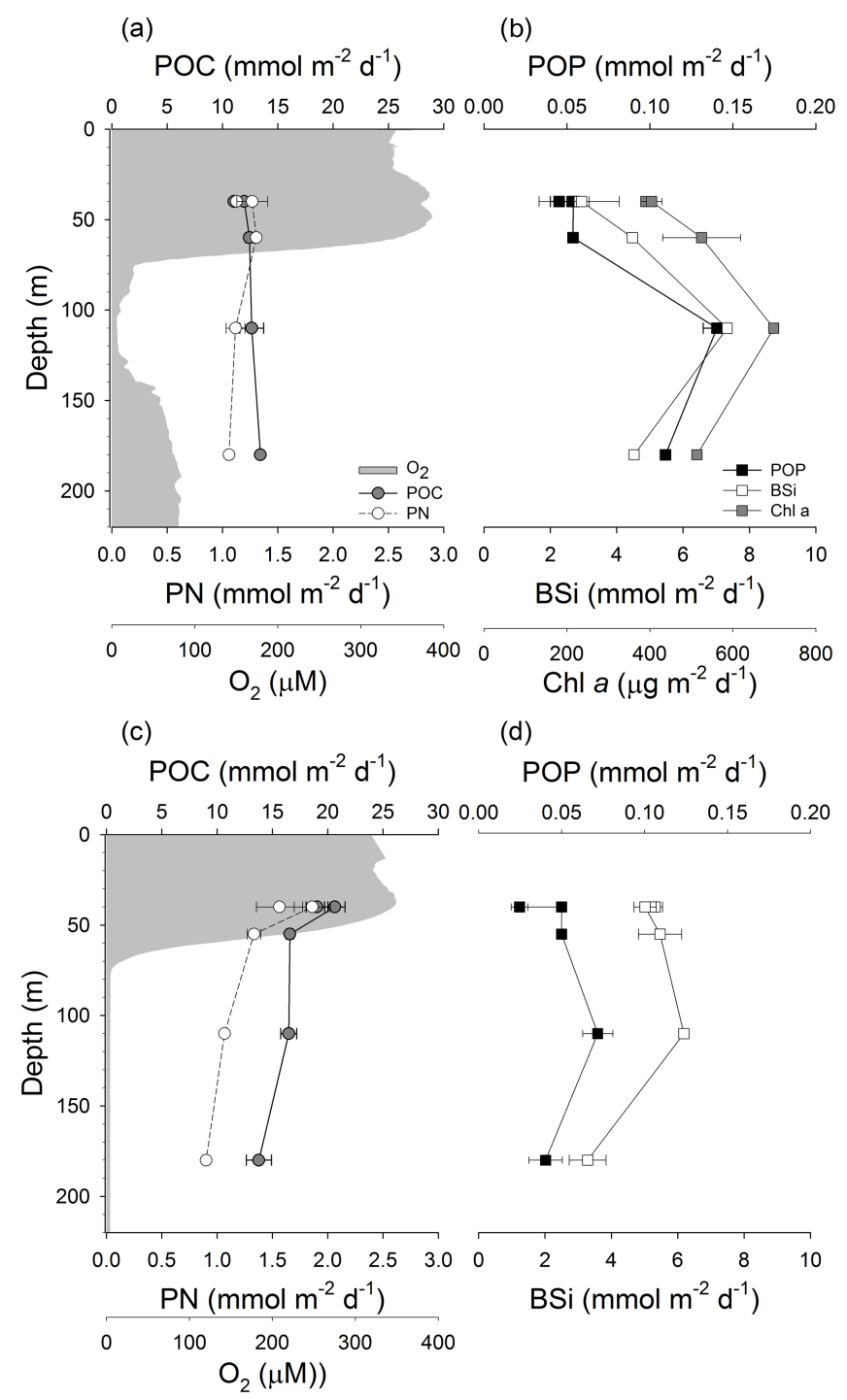

Figure 5. Vertical fluxes of particulate organic carbon (POC) and particulate nitrogen $(\mathrm{PN})$ as well as oxygen concentration in GB (a) and LD (c). Vertical fluxes of particulate organic phosphorus (POP), biogenic silica (BSi) and chlorophyll $a(\mathrm{Chl} a)$ in $\mathrm{GB}(\mathbf{b})$ and LD (d).

ticles associated with TEPs (Fig. 6a). In addition, TEP size distribution, determined by image analysis, indicated an increase in large TEPs at $110 \mathrm{~m}$ (data not shown). In contrast, in LD, POC, PN (Fig. 5c) and CSP (Fig. 6d) fluxes steadily decreased with depth by $28 \%, 42 \%$ and $56 \%$ from 40 to $180 \mathrm{~m}$. Similar to the fluxes measured in GB, the POP, BSi (Fig. 5d) and TEPs (Fig. 6c) showed a smaller peak in the sediment trap located at $110 \mathrm{~m}$.

MnOx-like particles were drastically less abundant in sediment trap samples from LD than in GB, and when present, they appeared as single particles, not aggregated with TEPs or CSPs (Fig. 6c, d). At both stations, and similar to the water column samples, MnOx-like particles were not observed 
Table 4. MnOx-like particle fluxes and size as equivalent spherical diameter (ESD) determined by image analysis in GB and LD.

\begin{tabular}{lrrrr}
\hline Station & $\begin{array}{r}\text { Depth } \\
(\mathrm{m})\end{array}$ & $\begin{array}{r}\text { MnOx-like particles } \\
\left(\mathrm{cm}^{2} \mathrm{~m}^{-2} \mathrm{~d}^{-1}\right)\end{array}$ & $\begin{array}{r}\text { Median size } \\
\text { ESD }(\mu \mathrm{m})\end{array}$ & $\begin{array}{r}\text { Size range } \\
\text { ESD }(\mu \mathrm{m})\end{array}$ \\
\hline GB & 110 & $5666 \pm 994$ & 2.8 & $0.6-167$ \\
& 180 & $7789 \pm 955$ & 3.3 & $0.6-153$ \\
\hline \multirow{2}{*}{ LD } & 110 & $50.3 \pm 1.8$ & 1.8 & $0.6-16.5$ \\
& 180 & $2.6 \pm 0.3$ & 1.4 & $1.2-9.3$ \\
\hline
\end{tabular}

in sediment trap samples collected in fully oxygenated waters $(40$ and $60 \mathrm{~m})$. The flux of MnOx-like particles at 110 and $180 \mathrm{~m}$ was 2 orders of magnitude larger in GB than in LD (Table 4). In GB, MnOx-like particles occurred as single particles as well as aggregates with each other and OM such as TEPs and CSPs (Fig. 6a, b, and e), phytoplankton cells, or detrital material. The ESD of MnOx-like particles and aggregates collected in the traps ranged from 0.6 to $167 \mu \mathrm{m}$ (median $2.8 \mu \mathrm{m}$ ) at $110 \mathrm{~m}$ and from 0.6 to $153 \mu \mathrm{m}$ (median $3.3 \mu \mathrm{m})$ at $180 \mathrm{~m}$. In LD, only a few single MnOx-like particles were observed at $110 \mathrm{~m}$ (Fig. 6c, d), and their size ranged from 0.6 to $16.5 \mathrm{~mm}$ (median 1.8) (Table 4).

TAA flux ranged from $371 \pm 12$ to $501 \pm 33 \mu \mathrm{mol} \mathrm{m}^{-2} \mathrm{~d}^{-1}$ in GB and from $502 \pm 84$ to $785 \pm 54 \mu \mathrm{mol} \mathrm{m}^{-2} \mathrm{~d}^{-1}$ in $\mathrm{LD}$ (Fig. 7a). In GB, the flux steadily decreased from the surface to depth, whereas in LD the TAA flux at $40 \mathrm{~m}$ was lower than at $60 \mathrm{~m}$ and decreased with depth from 60 to $180 \mathrm{~m}$ (Fig. 7b). The vertical profile of TCHO flux was similar at both stations, although the magnitude of the flux was higher at LD. The TCHO flux varied between $303 \pm 8$ and $428 \pm 14 \mu \mathrm{mol} \mathrm{m}^{-2} \mathrm{~d}^{-1}$ in GB (Fig. 7a) and between $503 \pm 19$ and $584 \pm 8 \mu \mathrm{mol} \mathrm{m}^{-2} \mathrm{~d}^{-1}$ in LD (Fig. 7b). At both stations, TCHO fluxes increased from 40 to $110 \mathrm{~m}$, where the highest flux was measured, and then it decreased at $180 \mathrm{~m}$.

\subsection{Chemical composition of sinking and suspended particles}

Comparing molar elemental ratios of sinking (from sediment trap material) and suspended (from water column) particles to the revisited Redfield ratio for living plankton (106C : 16N : 15Si : P; Redfield et al., 1963; Brzezinski, 1985), our results showed that the POC: $\mathrm{PN}$ ratio of sinking particles was slightly above this ratio at both stations. The POC:PN ratios of sinking particles in GB and $\mathrm{LD}$ were not significantly different. In GB, however, ratios increased with depth from 9.8 to 12.6, while in LD they varied between 11.1 and 15.4 without a clear trend with depth. The POC: POP ratio of sinking particles was lower $(p<0.05$; Mann-Whitney $U$ test $)$ in GB (90.1-244) than in LD (230-772) with the highest value observed at $40 \mathrm{~m}$ and the lowest at $110 \mathrm{~m}$. At both stations the POC: BSi ratios varied between 1.7 and 4.2, and $\mathrm{PN}$ : BSi ratios varied between 0.2 and 0.4 ; the lowest values were observed at $110 \mathrm{~m}$ (Table 5).

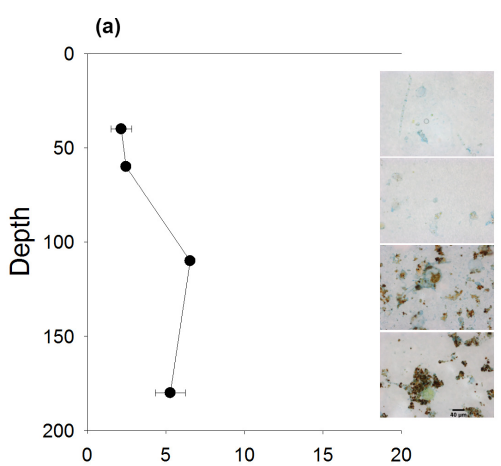

(b)
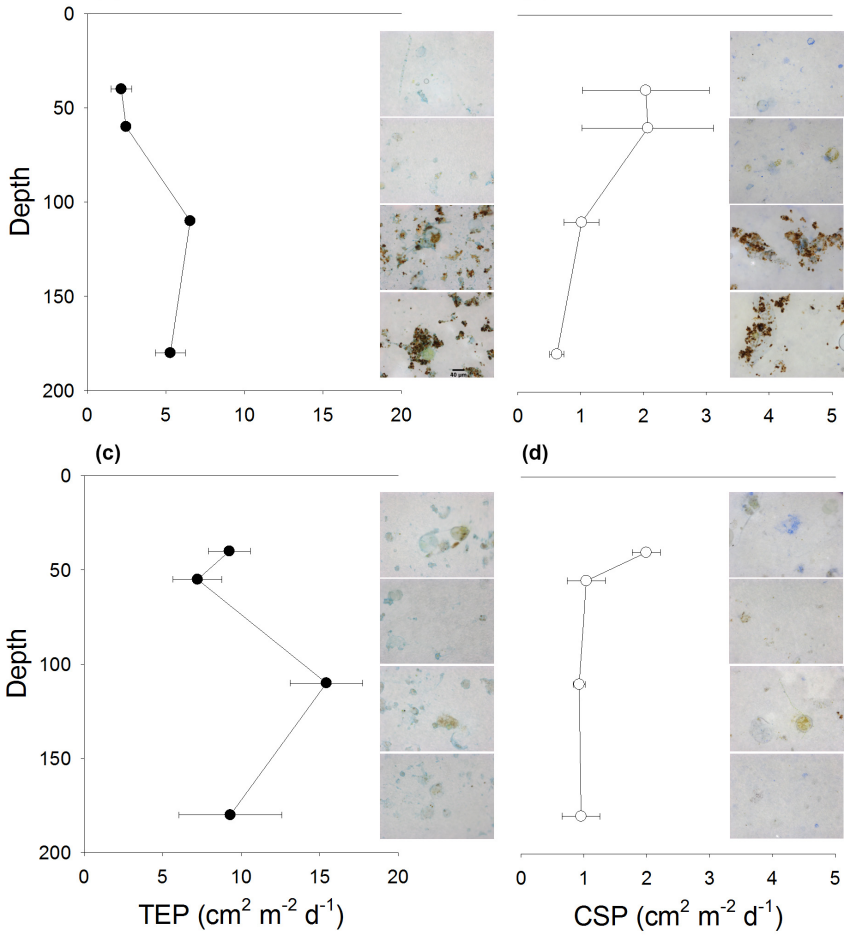

(d)

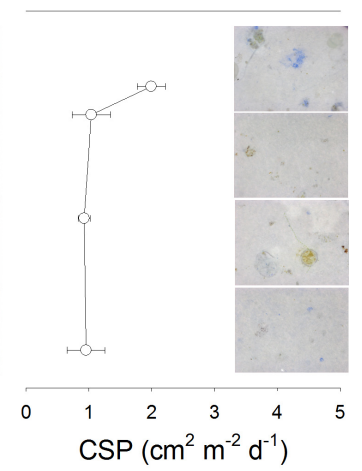

(e)

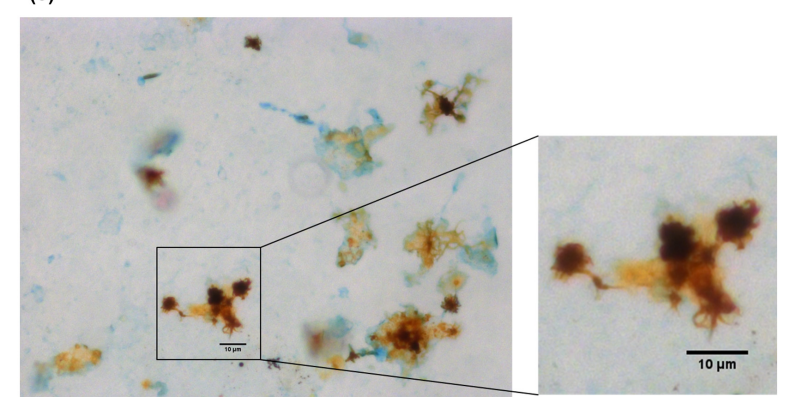

Figure 6. TEP and CSP fluxes in GB (a, b) and LD (c, d). In addition to vertical fluxes, each profile is complemented with microscopic images $(200 \times)$ of material collected at each depth. In GB, star-shaped MnOx-like particles are clearly visible as single particles and forming aggregates with TEPs (a) and CSPs (b). MnOxlike particles were less abundant in LD (c, d). (f) A larger magnification $(400 \times)$ image of $\mathrm{MnOx}$-like particles at $110 \mathrm{~m}$ showing more detail on the shape of particles and aggregates formed with TEPs.

Contrastingly, in suspended particles, POC: PN ratios were higher in GB than in $\mathrm{LD}(p<0.001)$. In GB, they varied between 8.4 and 12 without a clear trend with depth, while in LD, they decreased with depth from 8.7 (at $1 \mathrm{~m}$ ) to 6.2 (at $400 \mathrm{~m}$ ), and a slightly higher value of 7.8 was observed at $430 \mathrm{~m}$.

The POC: PN and POC:POP ratios were significantly higher $(p<0.01)$ in sinking than in suspended particles (Table 5). The POC:BSi and the PN:BSi ratios were much lower in sinking than in suspended particles at both stations (GB: $p<0.05$; LD: $p<0.01$ ). In sinking particles, the 
Table 5. Amino acids (AAa), carbohydrates (CHOs), elemental molar ratios and amino-acid-based degradation index of sinking and suspended particles in GB and in LD.

\begin{tabular}{|c|c|c|c|c|c|c|c|c|c|c|}
\hline & & Depth (m) & AA-C : POC \% & CHO-C: POC \% & POC: PN & POC : POP & POC: $\mathrm{BSi}$ & $\mathrm{PN}: \mathrm{BSi}$ & $\mathrm{PN}: \mathrm{POP}$ & DI \\
\hline \multirow{10}{*}{$\begin{array}{l}\text { Sinking } \\
\text { particles }\end{array}$} & GB & 40 & 19.2 & 18.3 & 9.8 & 244 & 3.9 & 0.4 & 24.9 & 1.49 \\
\hline & & 40 & 17.6 & 17.2 & 9.4 & 222 & 4.1 & 0.4 & 23.6 & 1.43 \\
\hline & & 60 & 15.8 & 17.6 & 9.5 & 232 & 2.8 & 0.3 & 24.3 & 1.13 \\
\hline & & 110 & 13.9 & 22.2 & 11.3 & 90.1 & 1.7 & 0.2 & 8.0 & 0.71 \\
\hline & & 180 & 11.1 & 18.5 & 12.7 & 123 & 3.0 & 0.2 & 9.7 & -0.03 \\
\hline & LD & 40 & 13.5 & 9.4 & 12.2 & 772 & 3.6 & 0.3 & 63.4 & 0.30 \\
\hline & & 40 & 14.3 & 8.4 & 11.1 & 413 & 4.1 & 0.4 & 37.2 & 0.27 \\
\hline & & 55 & 19.1 & 11.0 & 12.4 & 332 & 3.0 & 0.2 & 26.7 & -0.02 \\
\hline & & 110 & 13.4 & 12.0 & 15.4 & 230 & 2.7 & 0.2 & 14.9 & 0.11 \\
\hline & & 180 & 14.3 & 12.9 & 15.3 & 341 & 4.2 & 0.3 & 22.3 & -0.29 \\
\hline \multirow{21}{*}{$\begin{array}{l}\text { Suspended } \\
\text { particles }\end{array}$} & GB & 1 & 8.2 & 16.9 & 10.4 & 155 & 91.4 & 8.8 & 14.9 & \\
\hline & & 10 & 10.8 & 8.8 & 10.5 & 151 & 87.1 & 8.3 & 14.4 & \\
\hline & & 40 & 4.9 & 2.8 & 9.2 & 88.8 & 134 & 15 & 9.7 & -0.81 \\
\hline & & 60 & 5.4 & 2.7 & 9.8 & 127 & 125 & 13 & 13.0 & -0.27 \\
\hline & & 80 & 4.7 & 0.00 & 10.4 & 145 & & & 13.9 & \\
\hline & & 110 & 9.0 & 6.6 & 8.5 & 245 & & & 29.0 & 0.98 \\
\hline & & 140 & 5.3 & 0.00 & 10.6 & 283 & & & 26.7 & \\
\hline & & 180 & 5.7 & 4.3 & 11.4 & 506 & & & 44.5 & -0.40 \\
\hline & & 220 & 8.6 & 3.3 & 12.1 & 271 & & & 22.5 & \\
\hline & LD & 1 & 7.0 & 0.00 & 8.7 & 205 & 515 & 59.5 & 23.7 & \\
\hline & & 10 & 13.0 & 9.1 & 8.4 & 196 & 101 & 12.0 & 23.3 & \\
\hline & & 40 & 0.00 & 8.9 & 8.1 & 336 & 24.5 & 3.0 & 41.5 & -0.53 \\
\hline & & 60 & 6.1 & 10.3 & 7.8 & 301 & 16.9 & 2.2 & 38.4 & -0.12 \\
\hline & & 70 & 7.9 & 10.7 & 7.7 & 292 & 248 & 32.1 & 37.9 & \\
\hline & & 110 & 12.2 & 5.4 & 7.9 & 225 & & & 28.3 & 0.80 \\
\hline & & 180 & 10.1 & 11.3 & 7.0 & 205 & & & 29.2 & 0.34 \\
\hline & & 250 & 12.0 & 8.8 & 6.5 & 249 & & & 38.2 & \\
\hline & & 300 & 10.9 & 0.00 & 6.7 & 137 & & & 20.4 & \\
\hline & & 350 & 10.7 & 10.1 & 6.8 & 146 & & & 21.6 & \\
\hline & & 400 & 10.0 & 0.00 & 6.2 & 230 & & & 37.2 & \\
\hline & & 430 & 9.4 & 9.5 & 7.8 & 149 & & & 19.0 & \\
\hline
\end{tabular}

(a)

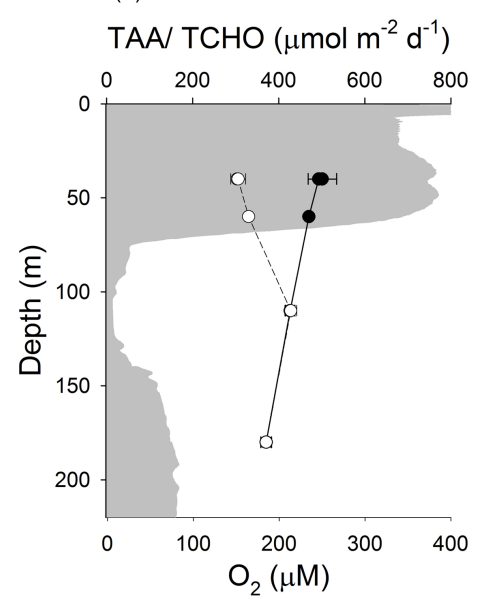

(b)

TAA/TCHO $\left(\mu \mathrm{mol} \mathrm{m} \mathrm{m}^{-2} \mathrm{~d}^{-1}\right)$
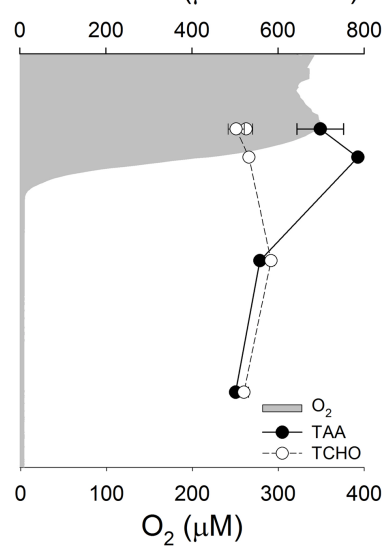

Figure 7. Vertical fluxes of total hydrolyzable amino acids (TAAs) and total carbohydrates (TCHOs) as well as oxygen concentration in (a) GB and (b) LD.
POC: BSi ratio was below the Redfield ratio of 7 , whereas it was 1 to 2 orders of magnitude higher in suspended particles (Table 5). The PN : POP ratio was significantly lower in sinking $(0.15-0.43)$ than in suspended particles $(9.7-44.5)$ at both stations $(p<0.001)$. In sinking particles, it was always below the Redfield ratio of 16 , while in suspended particles, it was in the range of the Redfield ratio in the upper $80 \mathrm{~m}$ in GB and always above in LD.

At both stations, the contribution of AA to POC was more significant in sinking than in suspended particles. Similarly, the carbon contained in TCHOs made up a larger percentage in sinking than in suspended particles (Table 5). The aminoacid-based degradation index (DI; Dauwe et al., 1999) varied from 0.1 to 1.14 in sinking $\mathrm{OM}$ and was higher than in suspended OM $(-1.25$ to -0.42$)$ at both stations. In sinking OM, the DI decreased with depth in GB, whereas in LD, there was not a clear trend with depth (Table 5). The DI was higher in GB than in LD in sinking as well as in suspended OM. 


\section{Discussion}

In this study, we (1) characterized the biogeochemistry of the water column and the sinking particles in GB and LD, during early summer 2015, and (2) determined the vertical flux of sinking particles in two deep basins of the Baltic Sea. Our results suggested that the intrusion of oxygenated water to GB, as a consequence of the 2014-2015 MBI, caused changes in the water chemistry that affected the chemical composition and degradation stage of the sinking and suspended particles. Consequently, the composition and magnitude of the sinking particle flux were different in GB and LD.

\subsection{Physical and biogeochemical conditions in GB and LD}

In general, physical and biogeochemical conditions (temperature, salinity, $\mathrm{O}_{2}$ and inorganic nutrient concentrations) were similar in the euphotic zone of both stations. Moreover, though there were slight differences between the stations concerning phytoplankton abundance and composition, as well as the concentration and chemical composition of POM, in the surface water column, those were not significant. The concentration of Chl $a$ (Fig. 3) and the abundance of picoplankton and nanophytoplankton (Table 2) were slightly higher (20\% and $10 \%$, respectively) in GB than in LD. This agrees with estimates of integrated total primary production (PP), which were $10 \%$ higher in GB ( $380 \mathrm{mg} \mathrm{C} \mathrm{m}^{-2} \mathrm{~d}^{-1}$ ) than in $\mathrm{LD}\left(334 \mathrm{mg} \mathrm{C} \mathrm{m}^{-2} \mathrm{~d}^{-1}\right.$; Piontek et al., unpublished). At both stations, the abundance of picophytoplankton $(<2 \mu \mathrm{m})$ was an order of magnitude higher than nanoplankton (Table 2). These findings coincided with what was described previously for early summer in the Baltic Sea, indicating that during this period productivity is sustained mostly by picophytoplankton and nanophytoplankton communities (Leppanen et al., 1994) that coexisted with cyanobacteria and other phytoplankton species (Kreus et al., 2015). Microscopic analysis, on the other hand, indicated that phytoplankton $(>5 \mu \mathrm{m})$ abundance was $47 \%$ higher in LD than in GB. At both stations, filamentous cyanobacteria ( $>90 \%$ Aphanizomenon sp.) were numerically the predominant phytoplankton type $(55 \%$ and $74 \%$ of the phytoplankton counts in GB and LD, respectively); dinoflagellates (including mixotrophs) correspond to $20 \%$, and diatoms correspond to $>1 \%$ of the phytoplankton abundance in the upper $40 \mathrm{~m}$ (Table 3). Diatoms were slightly higher in LD than in GB, and this coincided with a small peak in BSi concentration (1.5 $\mu \mathrm{M}$, Fig. 3e) at $40 \mathrm{~m}$ in LD. Although at both stations the diatom proportion from the total phytoplankton abundance was negligible, they could make a difference in the composition of sinking particles leaving the euphotic zone in LD due to the selective aggregation of diatoms (Passow et al., 1991); however, at both stations sinking particles showed a similar enrichment in BSi. The low abundance of diatoms relative to cyanobacteria in the euphotic zone indicated that at both stations, the spring bloom was terminated and cyanobacteria were starting to build up the summer bloom that generally occurs in June-July (Kreus et al., 2015). Aphanizomenon sp. and Nodularia spumigena are known to form summer blooms, in which they accumulate at the sea surface of the thermally stratified water column (Bianchi et al., 2000; Nausch et al., 2009; Wasmund, 1997).

The concentration of particulate elements (POC, PN, POP, BSi) was slightly higher in the surface waters of GB compared to LD, while exopolymeric particles containing polysaccharide (TEPs) and protein (CSPs) were in similar abundance at both stations. TEPs and CSPs were more abundant in the euphotic zone, which supports the idea of a phytoplankton origin; however, the concentration of TEPs in this study was $69 \%$ (in GB) and $76 \%$ (in LD) lower than previously reported for summer in the central Baltic Sea (Engel et al., 2002). Likewise, our dissolved inorganic nitrogen concentrations were below the detection limit in the surface, while phosphate concentrations were higher $(>0.3 \mu \mathrm{M})$ than observed in the Engel et al. (2002) study. Mari and Burd (1998) reported that TEP concentration peaked during the spring bloom and in summer in the Kattegat. TEP production may be enhanced by environmental conditions, such as nutrient limitation (Mari et al., 2005; Passow, 2002), which are characteristic of late summer in the Baltic Sea (Mari and Burd 1998). In the Baltic Sea, the spring bloom (March-April) is usually followed by a period of reduced PP (Chl $a \sim 2 \mu \mathrm{g} \mathrm{L}^{-1}$ ) that precedes the cyanobacteria summer bloom typically observed in June-July (Kreus et al., 2015). Surface satellite-derived Chl $a$ concentrations (MODIS) in GB constantly increase from mid-May to mid-June 2015 (Le Moigne et al., 2017); our monthly Chl $a$ concentrations derived from VIIRS for June 2015 in the Baltic Sea (Fig. 1) showed similar $\mathrm{Chl} a$ concentrations. Considering this trend in Chl $a$ concentration and the availability of phosphate in the water column, we could assume that our samples were collected at the beginning of the summer bloom (middle June). In general, ecosystem models from the Baltic Sea indicate that the termination of the summer bloom depends upon phosphate availability (Kreus et al., 2015). Thus, TEP concentrations likely had not reached the higher value previously observed after the summer bloom when inorganic nutrients were depleted. Although satellite-derived Chl $a$ concentrations is a valuable tool to evaluate the trend of PP, the magnitude of the concentration of $\mathrm{Chl} a$ from remote sensing is difficult to estimate in the Baltic Sea (Darecki and Stramski, 2004). The concentrations of Chl $a$ in GB and LD derived from direct measurements were much lower $\left(\sim 1.5 \mu \mathrm{g} \mathrm{L}^{-1}\right)$, suggesting that our samples were collected during a period of low phytoplankton biomass typically observed before the summer bloom. In any case, the concentration of phosphate was not limiting the system. Another possible explanation for the rather low concentrations of TEPs could be their removal from the surface by aggregation and subsequent sedimentation during the spring bloom due to the high abundance of 
cells and detrital particles during this time (Engel et al., 2002) and the relatively low grazing pressure that lead to higher export after the spring bloom (Lignell et al., 1993).

Although the composition and amount of OM in the surface waters at the two trap stations were similar, below the euphotic zone $(40 \mathrm{~m})$ the vertical profile of nutrients and particulate matter concentrations were distinctly different, likely due to the 2014-2015 MBI (Holtermann et al., 2017) that reached the deep waters of GB. This inflow replaced the old stagnant water masses with new water masses (Schmale et al., 2016), changing the salinity in the deepest waters and the vertical distribution of $\mathrm{O}_{2}$, limiting the oxygen-deficient layer from 74 to $140 \mathrm{~m}$, and ventilating the water column below $140 \mathrm{~m}$. The combination of physical effects (the displacement of water masses, turbulent mixing and lateral transport) and the consequent development of redox conditions through 2015 may have impacted the distribution of MnOx-like particles and POM in GB. In addition to changes in $\mathrm{O}_{2}$ concentration, the MBI altered the redox conditions in GB by creating a secondary redoxcline at $140 \mathrm{~m}$, where concentrations of $\mathrm{O}_{2}$ and $\mathrm{MnOx}$-like particles increased. One consequence of those changes is the vertical extension of the layer in which $\mathrm{MnOx}$-containing aggregates could form (Schmale et al., 2016); a previous study showed that MnOx might precipitate from the water column of GB following an MBI event (Lenz et al., 2015). POC and PN concentrations peaked at $110 \mathrm{~m}$, and this higher concentration at $110 \mathrm{~m}$ was even more evident in POP and TEPs, while CSP concentration peaked at $140 \mathrm{~m}$ (Fig. 3); this is the first study that examines the potential role of CSPs in forming aggregates with MnOx-containing particles. The highest concentration of MnOx-like particles (Fig. 4a) in the water column was not observed at $110 \mathrm{~m}$ (the core of the OMZ), but at $80 \mathrm{~m}$ (oxycline) and below $140 \mathrm{~m}$ in the newly oxygenated water layers.

In contrast, LD maintained permanent suboxic $\left(<5 \mu \mathrm{MO}_{2}\right)$ waters below $74 \mathrm{~m}$ and $\mathrm{H}_{2} \mathrm{~S}$ was detectable below $180 \mathrm{~m}$. Below $100 \mathrm{~m}$ the vertical profiles of POM and BSi did not change with depth. The only exception was TEP and CSP concentration that, similar to in GB, peaked at $110 \mathrm{~m}$ and $\mathrm{MnOx}$-like particles showed a small increment at $70 \mathrm{~m}$ (in the oxycline). This suggests that, similar to the results of Glockzin et al. (2014), the MnOx-like particles abundant in the oxycline may form sinking aggregates with TEPs and CSPs; then, when those aggregates sunk to anoxic waters (below $74 \mathrm{~m}$ ), the MnOx-like particles may have dissolved, releasing TEPs and CSPs to the water column where CSP concentration decreased quickly, likely due to microbial degradation, but the concentration of TEPs remained constant to the bottom of $\mathrm{LD}$.

MBIs can have a significant impact on nutrient recycling. In GB the nitrate concentration increased, possibly as a consequence of the oxidation of reduced nitrogen compounds (e.g., ammonium, ammonia and organic nitrogen compounds like urea) (Le Moigne et al., 2017) that accumulated during the stagnation (anoxic) period prior to the MBI (Hannig et al., 2007). Scavenging of phosphate onto $\mathrm{Mn}$ or $\mathrm{Fe}$ oxides has been shown in previous studies (Neretin et al., 2003). Phosphate can bind to $\mathrm{Fe}$ hydroxides and $\mathrm{MnOx}$ and settle down during oxic conditions, building up a phosphate pool in the sediments that later, when the $\mathrm{O}_{2}$ decreases, may become a source of phosphate (Gustafsson and Stigebrandt, 2007). Moreover, Myllykangas et al. (2017) reported that the new water masses intruded during the 2014-2015 MBI displaced the stagnant water masses in GB. Thus, the low concentrations of silicate and phosphate that we measured in the deep waters of GB may also be a direct consequence of the intrusion of oxygenated, low-nutrient waters associated with the MBI. In contrast, in LD, the water column remained anoxic down to the seafloor $(430 \mathrm{~m})$, and below the oxycline an increase in ammonium was observed (Fig. 2b), which could be an indicator for the anaerobic respiration of OM, e.g., denitrification (Bonaglia et al., 2016; Hietanen et al., 2012).

In summary, though GB and LD had similar surface conditions in terms of phytoplankton production and POM stocks, during this study, we found differences in the vertical concentration of nutrients (Fig. 2) and POM (Fig. 3) between GB, ventilated by the MBI, and $\mathrm{LD}$, a station that remained suboxic. Our results suggest that the MBI caused differences in the vertical profile of $\mathrm{O}_{2}$ that modified the redox conditions of the water column and enhanced the in situ formation of MnOx-like particles (Fig. 4). Alternatively, the inflow may transport new MnOx-like particles to GB. Those abundant MnOx-like particles may aggregate with POM in GB, influencing the vertical distribution of POM in the water column.

\subsection{Potential influence of $\mathrm{O}_{2}$ concentration and redox conditions on vertical flux of sinking particles in GB and LD}

During this study, we also investigated the effect of different $\mathrm{O}_{2}$ concentrations and redox conditions on the fluxes of particles. Our measurements of POC flux at $40 \mathrm{~m}$, below the euphotic zone, were $11.7 \pm 0.82 \mathrm{mmol} \mathrm{C} \mathrm{m}^{-2} \mathrm{~d}^{-1}$ in GB and $19.8 \pm 1.22 \mathrm{mmol} \mathrm{C} \mathrm{m}^{-2} \mathrm{~d}^{-1}$ in LD. Extrapolating those measurements to annual flux, we obtain $4.37 \pm$ $0.31 \mathrm{~mol} \mathrm{C} \mathrm{m}^{-2} \mathrm{yr}^{-1}$ in GB and $7.44 \pm 0.46 \mathrm{~mol} \mathrm{C} \mathrm{m}^{-2} \mathrm{yr}^{-1}$ in $\mathrm{LD}$. Our results from GB are in the same range as the estimation derived from a biogeochemical model; i.e., 3.8$4.2 \mathrm{~mol} \mathrm{C} \mathrm{m}^{-2} \mathrm{yr}^{-1}$ (Kreus et al., 2015; Sandberg et al., 2000; Stigebrandt, 1991) for the Baltic Sea. However, our results from LD are higher than the annual POC fluxes predicted by those models. The high POC flux observed in this study is not surprising since it represented one (in LD) and two (in GB) days in June when the POC vertical flux out of the euphotic zone is relatively high in the Baltic Sea compared with late fall and winter. The biogeochemical model by Markus Kreus (personal communication, 2015) estimated that POC flux in June ranged between 8 and 
$13 \mathrm{mmol} \mathrm{m}^{-2} \mathrm{~d}^{-1}$; this is in the same range as our observations.

One of the main advantages of our sediment traps is that we can study the flux of sinking particles at various depths simultaneously (i.e., higher vertical resolution). Therefore, we measured the POM flux in oxic waters (40 $\mathrm{m}$ and $60(55) \mathrm{m}$ ) at the core of the OMZ $(110 \mathrm{~m})$ and at $180 \mathrm{~m}$ in both basins. Traps located at $180 \mathrm{~m}$ of depth collected particles in sulfidic waters at LD and in recently oxygenated waters (affected by the MBI) in GB. The vertical flux of POM and BSi was different at the two studied basins; for example, POC flux was between $25 \%$ and $40 \%$ higher in the upper $110 \mathrm{~m}$ of the LD than in GB (even though the PP was $10 \%$ higher in GB). However, the POC fluxes at $180 \mathrm{~m}$ (deepest trap) were similar in both basins, indicating a substantial decrease in the POC flux between 110 and $180 \mathrm{~m}$ at the LD. The POC flux (and the PN flux, which showed a similar vertical profile) did not decrease with depth in the GB. In contrast, in the LD there was a reduction of $17 \%$ and $16 \%$ of the POC flux from 40 and $60 \mathrm{~m}$ (in the oxycline) and from 110 to $180 \mathrm{~m}$, respectively; the POC flux did not change from 60 to $110 \mathrm{~m}$ when a large section of the water column was suboxic $\left(\mathrm{O}_{2}<5 \mu \mathrm{M}\right.$ from $74 \mathrm{~m}$ to the bottom of the station). From 110 to $180 \mathrm{~m}$ the water column was completely anoxic, and $\mathrm{H}_{2} \mathrm{~S}$ was detectable at $180 \mathrm{~m}$. The high flux of POC at GB coincided with the appearance of dark, star-shaped particles that we defined as MnOx-like particles, particularly evident at GB (Fig. 6a, b, e), but also present in LD. Based on their morphology, size and aggregation with OM, we propose that those particles correspond to $\mathrm{MnOx}$-containing particles enriched in OM that have been previously described at GB (Neretin et al., 2003; Pohl et al., 2004; Glockzin et al., 2014; Dellwig et al., 2010, 2018) and LD (Glockzin et al., 2014; Dellwig et al., 2010). The higher flux of MnOx-like particles in GB than in LD is probably due to the oxygenation and changes in the deep water redox conditions that enhance the formation of MnOx-like particles associated with OM. This suggests that the reduction of the POC flux below $110 \mathrm{~m}$ in the LD may be related to the $\mathrm{O}_{2}$ depletion and the absence of $\mathrm{MnOx}-\mathrm{OM}$ aggregates in the anoxic zone.

The POP flux was similar in the oxic water column (up to $60 \mathrm{~m}$ ) in both basins; however, it was almost 2 and 3 times higher at 110 and $180 \mathrm{~m}$, respectively, in GB than in LD. A peak in the POP and BSi flux was observed at $110 \mathrm{~m}$ in both basins, but the magnitude of the increment was much higher in GB than in LD. In GB the POP flux increased $62 \%$ from 60 to $110 \mathrm{~m}$ (OMZ) and then decreased by $28 \%$ from 110 to $180 \mathrm{~m}$. Vertical fluxes of POP, BSi and Chl $a$ (Fig. 5) were enhanced at $110 \mathrm{~m}$, which coincided with the high flux of MnOx-like particles. This high flux of MnOx-like particles is maintained at $180 \mathrm{~m}$, while the POP, BSi and Chl $a$ flux decreased at this depth. This vertical distribution is likely due to the enhanced formation of $\mathrm{MnOx}$-like particles in the hypoxic layer $\left(<40 \mu \mathrm{M} \mathrm{O}_{2}\right)$ located between 74 and $140 \mathrm{~m}$ that may scavenge POP and aggregate with cells or phytodetritus containing BSi and Chl $a$. Although the POP flux peaked at $110 \mathrm{~m}$ in LD as well, the increment was only $30 \%$ from $60 \mathrm{~m}$ (suboxic) to $110 \mathrm{~m}$ (anoxic), and it decreased by $78 \%$ from 110 to $180 \mathrm{~m}$ (sulfidic waters); these variations with depth were also observed in the BSi flux. In LD, the flux and size of MnOx-like particles were much smaller than in GB, and they were more abundant at $110 \mathrm{~m}$ than at $180 \mathrm{~m}$.

Similar to the vertical distribution of POM in the water column discussed in Sect. 4.1, differences in POM and BSi fluxes between basins are likely associated with the large inflow of oxygen-rich saltwater that displaced the old stagnant water masses and changed the chemistry of the water column (Myllykangas et al., 2017). Under euxinic conditions (e.i., scenario observed in LD without the influence of the MBI), the maximum concentration of particulate $\mathrm{Mn}$ is found in the oxycline (Glockzin et al., 2014). Below the oxycline, and due to the presence of $\mathrm{H}_{2} \mathrm{~S}$, the particulate Mn concentration decreased drastically. During this study, we observed a high concentration of MnOx-like particles at 110 and $180 \mathrm{~m}$ (Table 5) in GB, in agreement with the high flux of particulate Mn measured in sediment traps located at $186 \mathrm{~m}$ in June 2015 (Dellwig et al., 2018). The oxygenation of the deep water layers of GB by the MBI caused the absence of $\mathrm{H}_{2} \mathrm{~S}$ (Schmale et al., 2016) and provided redox conditions favorable for the formation of $\mathrm{MnOx}$, resulting in the high MnOx-like particle fluxes measured in the sediment trap located in the core of the OMZ $(110 \mathrm{~m})$ and at $180 \mathrm{~m}$ (oxygenated deep water). There were two possible sources of $\mathrm{MnOx}$ associated with the 2014-2015 MBI in GB: the lateral transport of lowdensity aggregates formed by $\mathrm{MnOx}$ and $\mathrm{OM}$ (Glockzin et al., 2014) and the in situ formation and deposition of $\mathrm{MnOx}$ following the oxygenation of the water column (Dellwig et al., 2018). In clear contrast to the oxygenated deep layers of $\mathrm{GB}$, in $\mathrm{LD}$, we measured $\mathrm{H}_{2} \mathrm{~S}$ below $180 \mathrm{~m}$; this could explain why although those aggregates were present in this station at $110 \mathrm{~m}$, they may dissolve in sulfidic waters and thus were not as abundant and did not form aggregates with TEPs (Fig. 6c).

The presence of $\mathrm{MnOx}$-like particles in aggregates (Fig. 6a) may have implications for the vertical flux of POC, $\mathrm{PN}$ and POP in a stratified system with a pelagic redoxcline like the Baltic Sea. Under steady state, the upward diffusion and oxidation rates of the dissolved $\mathrm{Mn}$ are balanced by the sinking and dissolution rates of MnOx. During $\mathrm{Mn}$ oxidation, the $\mathrm{MnOx}$ could aggregate with POM and trace metals. Then, in the sulfidic waters, slow-sinking MnOx enriched in OM will be dissolved, liberating the OM and altering the vertical distribution and the flux of all associated particle elements (Glockzin et al., 2014). This has been previously observed in other anoxic basins; for example, in the Cariaco Basin, total particulate phosphorus reached a maximum flux in sediment traps close to the redoxcline (BenitezNelson et al., 2004, 2007). Moreover, even in the anoxic zone, the abundant aggregate-associated bacteria (Grossart et al., 2006) could partially or entirely degrade the organic 
compounds in particles using $\mathrm{NO}_{3}^{-}$or $\mathrm{MnOx}$ as an electron acceptor. This may explain why we observed a clear peak in the vertical fluxes of POP, BSi, Chl $a$ (Fig. 3a, b), TEPs (Fig. 6a) and TCHOs (Fig. 7a) at $110 \mathrm{~m}$, followed by a small decrease at $180 \mathrm{~m}$ in GB. In LD a smaller increment in the vertical fluxes of POP, BSi (Fig. 3d), TEPs (Fig. 6c) and TCHOs (Fig. 7b) was also observed. The vertical fluxes of those compounds coincided with the abundance of MnOxlike particles; we assume that the $\mathrm{MnOx}$ aggregated not only with TEPs as described before (Glockzin et al. 2014) and observed in this study (Fig. 6a), but also with aggregates containing phytoplankton cells and phytodetritus that may enhance POP, BSi, Chl $a$ and TCHO export. On the other hand, nitrogen-rich components of POM like PN (Fig. 3a), TAA (Fig. 7a) and CSPs (Fig. 6a) gradually decreased with depth in GB, suggesting that those compounds were less scavenged by $\mathrm{MnOx}-\mathrm{OM}$-rich aggregates.

PP in GB was $10 \%$ higher than in LD during our study (Piontek et al., unpublished data). However, the POC flux below the euphotic zone (at $40 \mathrm{~m}$ ) was $42 \%$ higher in LD than in GB and comparable at both stations at $180 \mathrm{~m}$. The fraction of PP exported as POC is termed export production (the $e$ ratio) (Buesseler et al., 1992), and it is calculated as the POC flux below the euphotic zone divided by the PP. We calculated the $e$ ratio using ${ }^{14} \mathrm{C}$-based PP measurements (Piontek et al., unpublished data) and carbon flux at $40 \mathrm{~m}$ (shallowest sediment trap depth considered at the base of the euphotic zone). The $e$ ratio was larger in LD (0.77) compared to GB (0.41); i.e., the percentage of the PP exported as POC below the euphotic zone was $77 \%$ in LD versus $41 \%$ in GB. This suggests that either a higher proportion of the PP was remineralized in the euphotic zone of GB compared with LD, or particles were sinking faster in LD than in GB, likely due to differences in composition. On the other hand, the transfer efficiency of POC to the deeper water column (i.e., the ratio of POC flux at $180 \mathrm{~m}$ over POC flux at $40 \mathrm{~m}$ ) was higher in GB $(115 \%)$ than in LD (69\%). The transfer efficiency of POM is largely controlled by the remineralization rate and the sinking velocity of particles (De La Rocha and Passow, 2007; McDonnell et al., 2015; Trull et al., 2008). The higher POC transfer efficiency in GB than in LD can be attributable to differences in the sinking velocities of the particles at those two stations. Particulate MnOx may sink through the redoxcline in GB (Neretin et al., 2003), acting as ballast material and a nucleus for $\mathrm{MnOx}-\mathrm{OM}$-rich aggregate formation. Those aggregates could have sunk more quickly, limiting the time spent in the water column and the degradation by particle-attached microbes. Assuming that MnOx-like particles had a density between 1.5 and $2.0 \mathrm{~g} \mathrm{~cm}^{-3}$ (Glockzin et al., 2014), the largest particles measured at GB $(167 \mu \mathrm{m}$, Table 4) will have a sinking velocity based on Stokes' law between 508 and $1014 \mathrm{md}^{-1}$. If we consider a mixed aggregate that is $50 \%$ TEPs (density $0.9 \mathrm{~g} \mathrm{~cm}^{-3}$ ) (Azetsu-Scott and Passow, 2004) and $50 \% \mathrm{MnOx}$ (density $1.5 \mathrm{~g} \mathrm{~cm}^{-3}$ ), its density would be $1.2 \mathrm{~g} \mathrm{~cm}^{-3}$, and its theoretical sinking ve- locity will be $204 \mathrm{md}^{-1}$. This indicates that, theoretically, the largest mixed aggregates composed of MnOx and TEPs observed in GB could reach $180 \mathrm{~m}$ (the location of our deepest sediment trap) in less than 1 day. However, the average measured sinking velocity of MnOx-containing particles in the laboratory for particles between 2 and $20 \mu \mathrm{m}$ was $0.76 \mathrm{~m} \mathrm{~d}^{-1}$, which is significantly lower than the theoretical value (Glockzin et al., 2014). Glockzin et al. (2014) suggested that the star shape and the content of OM were responsible for the lower-than-predicted sinking velocity. There is no information about the amount of OM relative to $\mathrm{MnOx}-$ containing particles in those mixed aggregates or how the MnOx-to-OM ratio may affect the density and sinking velocity of larger aggregates like the ones we observed. Due to the shape and size of $\mathrm{MnOx}-\mathrm{OM}$ aggregates observed in our study (Fig. 6e), we could assume those are the same type of aggregates described before by Glockzin et al. (2014). Although we did not measure the sinking velocity of those aggregates, we did observe a higher abundance of them associated with TEPs at 110 and $180 \mathrm{~m}$ in GB than in LD. Thus, the formation of $\mathrm{MnOx}$ aggregates rich in OM could represent an additional mechanism (see the Introduction) to explain why the efficiency of OM export is different under anoxic than under oxic conditions in the Baltic Sea. The oxygenation of anoxic deep water in GB caused by the 2014-2015 MBI may have led to enhanced precipitation of manganese, iron and phosphorus particles (Dellwig et al., 2010, 2018). For example, the formation of P-rich metal oxide precipitates occurs in the anoxic waters of the Black Sea (Shaffer, 1986) and Cariaco Basin (Benitez-Nelson et al., 2004, 2007) where higher concentrations of particulate inorganic and organic phosphorus have been observed in sediment traps close to the redoxcline.

Alternatively, BSi could also act as ballast material incrementing the sinking velocity of marine aggregates (Armstrong et al., 2002; Klaas and Archer, 2002). Our results showed that sinking particles were strongly enriched in BSi relatively to $\mathrm{C}$ and $\mathrm{N}$ and compared to suspended particles that were depleted in BSi (Table 5). Diatoms are the major phytoplankton group that produces BSi to build their cell walls (Martin-Jézéquel et al., 2000), and they are the dominant phytoplankton species during the spring bloom. However, during our study, diatoms represented less than $1 \%$ of the phytoplankton abundance in the water column, and even though there was a strong enrichment in BSi in the sinking particles, this was similar in GB and LD (Table 5). Therefore, neither the differences in export production nor in transfer efficiency between GB and LD could be solely explained by the amount of diatoms cells, phytodetritus or BSi in sinking particles at the two basins. 


\subsection{Differences in composition and lability of sinking and suspended organic matter in GB and LD}

In the sections above we compared the biogeochemical conditions and the size of the POM pool in the euphotic zone of GB and LD. We then looked at how the sinking flux of $\mathrm{OM}$ was affected by the different $\mathrm{O}_{2}$ concentrations in the water column. Now, we focus on the influence of $\mathrm{O}_{2}$ in the chemical composition of sinking and suspended particles. Suspended or slow-sinking particles that spend more time in the water column should theoretically show a more substantial degree of degradation (Goutx et al., 2007) relative to the Redfield molar ratio: 106 POC: 16 PN : 15 BSi : POP. POM showed enrichment in POC relative to PN and POP, especially in sinking particles from $L D$ and suspended particles from GB. Our measured values of POC: $\mathrm{PN}(\sim 10)$ and POC: POP (between 89 and 506) in suspended OM coincide with the simulated ratio reported immediately after the culmination of the spring bloom by Kreus et al. (2015). The same study had suggested that POC: POP higher than the Redfield ratio might lead to an enhancement of particle export (Kreus et al., 2015); however, no direct observations had confirmed this hypothesis. Our measurements showed that the relative higher POC : POP ratios in sinking OM from LD, compared with GB, do not lead to a higher transfer efficiency at this station. Compared to the suspended OM in $\mathrm{LD}$, the POP content was lower in GB, possibly related to scavenging of POP into MnOx aggregates (see Sect. 3.4).

In addition, at both stations, sinking particles were strongly enriched in BSi (Table 5), probably due to the preferential sinking of diatoms and remnant diatom-rich detritus from the spring bloom. Differently, suspended particles had a relatively low content of $\mathrm{BSi}$; this is not surprising considering the small proportions of diatoms in the euphotic zone at the time of our sampling. The concentration of BSi decreased below the detection limit from $60 \mathrm{~m}$ in the GB and $70 \mathrm{~m}$ in the LD. This observation coincides with previous studies reporting the selective incorporation of diatoms into sinking aggregates in the Baltic Sea (Engel et al., 2002; Passow, 1991), whereas non-diatom species, although they may be abundant in the suspended phytoplankton, may not be present in sinking particles (Passow, 1991).

Another explanation for higher BSi content in sinking particles may be the inclusion of lithogenic Si in our measurements; lithogenic Si may have been present in the water column or transported by laterally adverted material. A recent study suggests that contributions of non-biogenic sources could be significant during alkaline extraction (Barão et al., 2015). The even more substantial enrichment in BSi observed in sinking particles from $110 \mathrm{~m}$ in both basins may result from adsorption and/or coprecipitation of silica in sinking particles containing MnOx (Dellwig et al., 2010; Hartmann, 1985) or from the formation of aggregates that are enriched in MnOx as well as in phytodetritus of diatom origin.
The TAA-based degradation index, DI (Dauwe et al. 1999), covers a wide range of alteration stages; the more negative the DI, the more degraded the samples, and positive DI indicates fresh organic matter. In our study, the sediment trap material had a DI between 0.10 and 1.14 , while suspended $\mathrm{OM}$ has a DI between -0.26 and -1.25 (Table 5). These values coincide with what was reported earlier by Dauwe et al. (1999) and indicate that, first, the sinking particles collected in the sediment traps were less altered (they have a more positive DI) than the suspended OM collected in the Niskin bottle. Second, sinking particles from GB were fresher than the ones from LD, and the degradation stage increased with depth at both stations. The higher contribution of AA and $\mathrm{CHO}$ to the POC pool in sinking than in suspended $\mathrm{OM}$ and the AA-DI indicates that suspended OM was more degraded than sinking OM. The highest degree of degradation in suspended OM and sinking OM from LD may be the result of a long time that light-suspended OM or slowsinking particles spend exposed to degradation in fully oxygenated surface waters than dense, fast-sinking particles collected in sediment traps.

The higher abundance of aggregates, formed by a combination of MnOx-like particles and OM, observed at 110 and $180 \mathrm{~m}$ in GB could act as bacteria hot spots that, combined with a higher $\mathrm{O}_{2}$ concentration in GB, may increase the microbial degradation on sinking particles collected in GB. However, the AA-DI indicated that sinking OM was less altered and therefore more labile than the sinking $\mathrm{OM}$ in LD. This implied that in addition to the higher transfer efficiency of POC in GB (see discussion above), the OM reaching the seafloor was fresher and less degraded. This supports the idea that mixed aggregates composed of $\mathrm{MnOx}$ and $\mathrm{OM}$ may be larger and faster sinking than previously described by Glockzin et al. (2014). This explanation is mostly speculative and based on the observation of large mixed aggregates in the 110 and $180 \mathrm{~m}$ traps (Fig. 6, Table 4). However, as mentioned in the previous section, further work on directly determining sinking velocity is required to prove this hypothesis.

\section{Conclusions}

The fluxes and composition of sinking particles were different in two deep basins in the Baltic Sea (GB and LD) during early summer 2015 . The two stations had similar surface characteristics and POM stock; however, at depth, the vertical profile of the POM concentration, as well as the vertical flux of sinking particles, was different, likely related to differences in the $\mathrm{O}_{2}$ concentration. The 2014-2015 MBI supplied oxygen-rich waters to $\mathrm{GB}$, transporting solid material from shallower areas and modifying the $\mathrm{O}_{2}$ vertical profile and the redox conditions in the otherwise permanent suboxic deep waters. This event did not affect LD, allowing for the comparison of POM fluxes and composition under two different $\mathrm{O}_{2}$ concentrations with similar surface water con- 
ditions. Export efficiency ( $e$ ratio) derived from in situ PP measurements and POC flux derived from sediment traps indicated higher export efficiency in LD than in GB. However, the transfer efficiency (POC flux at $180 \mathrm{~m}$ over POC flux at $40 \mathrm{~m}$ ) suggested that under the anoxic conditions found in $\mathrm{LD}$, a smaller portion of the POC exported below the euphotic zone was transferred to $180 \mathrm{~m}$ than under the oxygenated conditions present in GB. The MBIs also transport solid Mn from shallower areas towards GB that may have contributed to the higher abundance of $\mathrm{MnOx}-\mathrm{OM}$ in GB. Our results suggest that a new possible mechanism to explain the differences in $\mathrm{OM}$ fluxes under different $\mathrm{O}_{2}$ concentrations could be the formation and prevalence of aggregates composed of MnOx and organic matter in GB. Those aggregates were significantly larger and more abundant in GB compared to LD where sulfidic waters constrained their presence. Our results indicate that at GB not only a higher proportion of the POM leaving the euphotic zone reached our deepest sediment trap, but also that this POM was fresher and less degraded. We propose that after an MBI in GB, aggregates containing MnOx-like particles and organic matter could have reached the sediments relatively fast and unaltered, scavenging not only phosphorus and TEPs, as described previously, but also other compounds like BSi, POP and CSPs. The higher fraction of sinking particles exported below the euphotic zone and reaching $180 \mathrm{~m}$ in GB suggests that at this station a significant fraction of the POM could reach the sediments, $50 \mathrm{~m}$ below our deepest sediment trap, relatively unaltered. The remineralization of the organic matter reaching the sediments may contribute to the quick reestablishment of anoxic conditions in the sediment-water interface in GB. The relevance of this process needs to be further investigated in order to be included in $\mathrm{O}_{2}$ budget and long-term predictions of the MBI impact on $\mathrm{O}_{2}$ and $\mathrm{OM}$ cycles.

Data availability. All data will become available at https://doi.org/10.1594/PANGAEA.898738 upon publication.

Author contributions. CCN designed and performed the sediment trap work at sea, analyzed samples, and wrote the paper. FACLM designed and performed the sediment trap work at sea and contributed to the writing of the paper. AE designed and participated in the scientific program at sea and discussed and commented on the paper.

Competing interests. The authors declare that they have no conflict of interest.

Acknowledgements. This research was supported by the DFG Collaborative Research Center 754 "Climate-Biogeochemistry Interactions in the Tropical Ocean" (to Anja Engel, Carolina
Cisternas-Novoa and Frédéric A. C. Le Moigne), by a Fellowship of the Excellence Cluster "The Future Ocean" (CP1403 to Frédéric A. C. Le Moigne), and by a DAAD short-term grant (57130097 to Carolina Cisternas-Novoa). We thank Jon Roa, Tania Klüver, Scarlett Sett, Angela Stippkugel, Carola Wagner, Clarissa Karthäuser, Moritz Ehrlich, Sonja Endres, Hannes Wagner, Ruth Flerus, Sven Sturm and Christian Begler for support during trap preparation and deployments, as well as help with experiment or analyzed samples. We thank Judith Piontek for her contribution to the design of the scientific program at sea, Jaime Soto-Neira for valuable discussion and help with figure preparation, Annegret Stuhr for useful discussion about phytoplankton data, and Cindy Lee for helpful advice. We gratefully acknowledge the reviewers, Monika Nausch and Tom Jilbert, and the associated editor Marcel van der Meer for their time and effort in reviewing and editing the paper, which significantly improved this publication.

The article processing charges for this open-access

publication were covered by a Research

Centre of the Helmholtz Association.

Edited by: Marcel van der Meer

Reviewed by: Tom Jilbert and one anonymous referee

\section{References}

Andersen, J. H., Carstensen, J., Conley, D. J., Dromph, K., FlemingLehtinen, V., Gustafsson, B. G., Josefson, A. B., Norkko, A., Villnäs, A., and Murray, C.: Long-term temporal and spatial trends in eutrophication status of the Baltic Sea, Biol. Rev., 92, 135-149, 2017.

Armstrong, R. A., Lee, C., Hedges, J. I., Honjo, S., and Wakeham, S. G.: A new, mechanistic model for organic carbon fluxes in the ocean based on the quantitative association of POC with ballast minerals, Deep-Sea Res. Pt. II, 49, 219-236, 2002.

Azetsu-Scott, K. and Passow, U.: Ascending marine particles: Significance of transparent exopolymer particles (TEP) in the upper ocean, Limnol. Oceanogr., 49, 741-748, 2004.

Barão, L., Vandevenne, F., Clymans, W., Frings, P., Ragueneau, O., Meire, P., Conley, D. J., and Struyf, E.: Alkaline-extractable silicon from land to ocean: A challenge for biogenic silicon determination, Limnol. Oceanogr.-Meth., 13, 329-344, 2015.

Benitez-Nelson, C. R., O'Neill, L., Kolowith, L. C., Pellechia, P., and Thunel, R.: Phosphonates and particulate organic phosphorus cycling in an anoxic marine basin, Limnol. Oceanogr., 49, 1593-1604, 2004.

Benitez-Nelson, C. R., O’Neill Madden, L. P., Styles, R. M., Thunell, R. C., and Astor, Y.: Inorganic and organic sinking particulate phosphorus fluxes across the oxic/anoxic water column of Cariaco Basin, Venezuela, Mar. Chem., 105, 90-100, 2007.

Bianchi, T. S., Engelhaupt, E., Westman, P., Andrén, T., Rolff, C., and Elmgren, R.: Cyanobacterial blooms in the Baltic Sea: Natural or human-induced?, Limnol. Oceanogr., 45, 716-726, 2000.

Bonaglia, S., Klawonn, I., Brabandere, L. D., Deutsch, B., Thamdrup, B., and Brüchert, V.: Denitrification and DNRA at the Baltic Sea oxic-anoxic interface: Substrate spectrum and kinetics, Limnol. Oceanogr., 61, 1900-1915, 2016. 
Boyd, P. W. and Trull, T. W.: Understanding the export of biogenic particles in oceanic waters: Is there consensus?, Prog. Oceanogr., 72, 276-312, 2007.

Bradford, M. M.: A rapid and sensitive method for the quantitation of microgram quantities of protein utilizing the principle of protein-dye binding, Anal. Biochem., 72, 248-254, 1976.

Brettar, I. and Rheinheimer, G.: Denitrification in the Central Baltic: evidence for $\mathrm{H}_{2} \mathrm{~S}$-oxidation as motor of denitrification at the oxic-anoxic interface, Mar. Ecol. Prog. Ser., 77, 157-169, 1991.

Brzezinski, M. A.: The Si-C-N Ratio of Marine Diatoms - Interspecific Variability and the Effect of Some Environmental Variables, J. Phycol., 21, 347-357, 1985.

Buesseler, K. O., Bacon, M. P., Kirk Cochran, J., and Livingston, H. D.: Carbon and nitrogen export during the JGOFS North Atlantic Bloom experiment estimated from ${ }^{234} \mathrm{Th}:{ }^{238} \mathrm{U}$ disequilibria, Deep-Sea Res., 39, 1115-1137, 1992.

Carstensen, J., Andersen, J. H., Gustafsson, B. G., and Conley, D. J.: Deoxygenation of the Baltic Sea during the last century, P. Natl. Acad. Sci. USA, 111, 5628-5633, 2014a.

Carstensen, J., Conley, D. J., Bonsdorff, E., Gustafsson, B. G., Hietanen, S., Janas, U., Jilbert, T., Maximov, A., Norkko, A., Norkko, J., Reed, D. C., Slomp, C. P., Timmermann, K., and Voss, M.: Hypoxia in the Baltic Sea: Biogeochemical Cycles, Benthic Fauna, and Management, AMBIO, 43, 26-36, $2014 \mathrm{~b}$.

Cavan, E. L., Trimmer, M., Shelley, F., and Sanders, R.: Remineralization of particulate organic carbon in an ocean oxygen minimum zone, Nat. Commun., 8, 14847, https://doi.org/10.1038/ncomms14847, 2017.

Cisternas-Novoa, C., Lee, C., and Engel, A.: A semi-quantitative spectrophotometric, dye-binding assay for determination of Coomassie Blue stainable particles, Limnol. Oceanogr.-Meth., 12, 604-616, 2014.

Cisternas-Novoa, C., Lee, C., and Engel, A.: Transparent exopolymer particles (TEP) and Coomassie stainable particles (CSP): Differences between their origin and vertical distributions in the ocean, Mar. Chem., 175, 56-71, 2015.

Conley, D. J., Björck, S., Bonsdorff, E., Carstensen, J., Destouni, G., Gustafsson, B. G., Hietanen, S., Kortekaas, M., Kuosa, H., Markus Meier, H. E., Müller-Karulis, B., Nordberg, K., Norkko, A., Nürnberg, G., Pitkänen, H., Rabalais, N. N., Rosenberg, R., Savchuk, O. P., Slomp, C. P., Voss, M., Wulff, F., and Zillén, L.: Hypoxia-Related Processes in the Baltic Sea, Environ. Sci. Technol., 43, 3412-3420, 2009.

Conte, M. H., Ralph, N., and Ross, E. H.: Seasonal and interannual variability in deep ocean particle fluxes at the Oceanic Flux Program (OFP)/Bermuda Atlantic Time Series (BATS) site in the western Sargasso Sea near Bermuda, Deep-Sea Res. Pt. II, 48, 1471-1505, 2001.

Darecki, M. and Stramski, D.: An evaluation of MODIS and SeaWiFS bio-optical algorithms in the Baltic Sea, Remote Sens. Environ., 89, 326-350, 2004.

Dauwe, B., Middelburg, J. J., Herman, P. M. J., and Heip, C. H. R.: Linking diagenetic alteration of amino acids and bulk organic matter reactivity, Limnol. Oceanogr., 44, 1809-1814, 1999.

De La Rocha, C. L. and Passow, U.: Factors influencing the sinking of POC and the efficiency of the biological carbon pump, DeepSea Res. Pt. II, 54, 639-658, 2007.

Dellwig, O., Leipe, T., März, C., Glockzin, M., Pollehne, F., Schnetger, B., Yakushev, E. V., Böttcher, M. E., and Brumsack, H.-J.:
A new particulate $\mathrm{Mn}-\mathrm{Fe}-\mathrm{P}$-shuttle at the redoxcline of anoxic basins, Geochim. Cosmochim. Ac., 74, 7100-7115, 2010.

Dellwig, O., Schnetger, B., Brumsack, H.-J., Grossart, H.-P., and Umlauf, L.: Dissolved reactive manganese at pelagic redoxclines (part II): Hydrodynamic conditions for accumulation, J. Marine Syst., 90, 31-41, 2012.

Dellwig, O., Schnetger, B., Meyer, D., Pollehne, F., Häusler, K., and Arz, H. W.: Impact of the Major Baltic Inflow in 2014 on Manganese Cycling in the Gotland Deep (Baltic Sea), Frontiers in Marine Science, 5, 248 pp., 2018.

Devol, A. H. and Hartnett, H. E.: Role of the oxygen-deficient zone in transfer of organic carbon to the deep ocean, Limnol. Oceanogr., 46, 1684-1690, 2001.

Dittmar, T., Cherrier, J., and Ludwichowski, K. U.: The analysis of amino acids in seawater, in: Practical guidelines for the analysis of seawater, edited by: Wurl, O., CRC Press, Boca Raton, 2009.

Dollhopf, M. E., Nealson, K. H., Simon, D. M., and Luther, G. W.: Kinetics of $\mathrm{Fe}(\mathrm{III})$ and $\mathrm{Mn}(\mathrm{IV})$ reduction by the Black Sea strain of Shewanella putrefaciens using in situ solid state voltammetric Au/Hg electrodes, Mar. Chem., 70, 171-180, 2000.

Dugdale, R. C. and Goering, J. J.: Uptake Of New And Regenerated Forms Of Nitrogen In Primary Productivity, Limnol. Oceanogr., 12, 196-206, 1967.

Emeis, K. C., Struck, U., Leipe, T., Pollehne, F., Kunzendorf, H., and Christiansen, C.: Changes in the $\mathrm{C}, \mathrm{N}, \mathrm{P}$ burial rates in some Baltic Sea sediments over the last 150 years - relevance to $\mathrm{P}$ regeneration rates and the phosphorus cycle, Mar. Geol., 167, 4359, 2000.

Engel, A.: The role of transparent exopolymer particles (TEP) in the increase in apparent particle stickiness $(\alpha)$ during the decline of a diatom bloom, J. Plankton Res., 22, 485-497, 2000.

Engel, A.: Determination of marine gel particles in Practical Guidelines for the Analysis of Seawater, CRC Press Taylor \& Francis Group, Boca Raton, FL, 2009.

Engel, A. and Händel, N.: A novel protocol for determining the concentration and composition of sugars in particulate and in high molecular weight dissolved organic matter (HMW-DOM) in seawater, Mar. Chem., 127, 180-191, 2011.

Engel, A. and Schartau, M.: Influence of transparent exopolymer particles (TEP) on sinking velocity of Nitzschia closterium aggregates, Mar. Ecol. Prog. Ser., 182, 69-76, 1999.

Engel, A., Meyerhöfer, M., and von Bröckel, K.: Chemical and Biological Composition of Suspended Particles and Aggregates in the Baltic Sea in Summer (1999), Estuar. Coast. Shelf S., 55, 729-741, 2002.

Engel, A., Wagner, H., Le Moigne, F. A. C., and Wilson, S. T.: Particle export fluxes to the oxygen minimum zone of the eastern tropical North Atlantic, Biogeosciences, 14, 1825-1838, https://doi.org/10.5194/bg-14-1825-2017, 2017.

Eppley, R. W. and Peterson, B. J.: Particulate organic matter flux and planktonic new production in the deep ocean, Nature, 282, 677-680, https://doi.org/10.1038/282677a0, 1979.

Glockzin, M., Pollehne, F., and Dellwig, O.: Stationary sinking velocity of authigenic manganese oxides at pelagic redoxclines, Mar. Chem., 160, 67-74, 2014.

Goutx, M., Wakeham, S. G., Lee, C., Duflos, M., Guigue, C., Liu, Z., Moriceau, B., Sempére, R., Tedetti, M., and Xue, J.: Composition and degradation of marine particles with different set- 
tling velocities in the northwestern Mediterranean Sea, Limnol. Oceanogr., 52, 1645-1664, 2007.

Grasshoff, K., Ehrhardt, M., and Kremling, K.: Methods of Seawater Analysis 3rd ed., in: Internationale Revue der gesamten Hydrobiologie und Hydrographie, Wiley-VCH, Weinheim, Germany, 1999.

Grossart, H. P., Kiørboe, T., Tang, K. W., Allgaier, M., Yam, E. M., and Ploug, H.: Interactions between marine snow and heterotrophic bacteria: aggregate formation and microbial dynamics, Aquat. Microb. Ecol., 42, 19-26, 2006.

Gustafsson, B. G. and Stigebrandt, A.: Dynamics of nutrients and oxygen/hydrogen sulfide in the Baltic Sea deep water, J. Geophys. Res.-Biogeo., 112, https://doi.org/10.1029/2006JG000304, 2007.

Hannig, M., Lavik, G., Kuypers, M. M. M., Woebken, D., MartensHabbena, W., and Jürgens, K.: Shift from denitrification to anammox after inflow events in the central Baltic Sea, Limnol. Oceanogr., 52, 1336-1345, 2007.

Hansen, H. P. and Koroleff, F.: Determination of nutrients, in: Methods of Seawater Analysis, edited by: Grasshoff, K., Kremling, K., and Ehrhardt, M., Willey-VCH, Weinheim, Germany, 1999.

Hansen, H. P. and Koroleff, F.: Determination of nutrients, in: Methods of Seawater Analysis, Wiley-VCH Verlag GmbH, Weinheim, Germany, 2007.

Hartmann, M.: Atlantis-II Deep geothermal brine system. Chemical processes between hydrothermal brines and Red Sea deep water, Mar. Geol., 64, 157-177, 1985.

HELCOM: Guidelines for monitoring phytoplankton species composition, abundance and biomass, in: Manual for Marine Monitoring in the COMBINE Programme of HELCOM, Helsinki Commission, Helsinki, 2012.

Hietanen, S., Jäntti, H., Buizert, C., Jürgens, K., Labrenz, M., Voss, M., and Kuparinen, J.: Hypoxia and nitrogen processing in the Baltic Sea water column, Limnol. Oceanogr., 57, 325-337, 2012.

Holtermann, P. L., Prien, R., Naumann, M., Mohrholz, V., and Umlauf, L.: Deepwater dynamics and mixing processes during a major inflow event in the central Baltic Sea, J. Geophys. Res.Oceans, 122, 6648-6667, 2017.

Kalvelage, T., Lavik, G., Lam, P., Contreras, S., Arteaga, L., Löscher, C. R., Oschlies, A., Paulmier, A., Stramma, L., and Kuypers, M. M. M.: Nitrogen cycling driven by organic matter export in the South Pacific oxygen minimum zone, Nat. Geosci., 6, 228, 2013.

Keil, R. G., Neibauer, J. A., Biladeau, C., van der Elst, K., and Devol, A. H.: A multiproxy approach to understanding the "enhanced" flux of organic matter through the oxygen-deficient waters of the Arabian Sea, Biogeosciences, 13, 2077-2092, https://doi.org/10.5194/bg-13-2077-2016, 2016.

Klaas, C. and Archer, D. E.: Association of sinking organic matter with various types of mineral ballast in the deep sea: Implications for the rain ratio, Global Biogeochem. Cy., 16, 63-61-6314, 2002.

Knauer, G. A., Martin, J. H., and Bruland, K. W.: Fluxes of particulate carbon, nitrogen, and phosphorus in the upper water column of the northeast Pacific, Deep-Sea Res., 26, 97-108, 1979.

Kreus, M., Schartau, M., Engel, A., Nausch, M., and Voss, M.: Variations in the elemental ratio of organic matter in the central Baltic Sea: Part I - Linking primary production to remineralization, Cont. Shelf. Res., 100, 25-45, 2015.
Kullenberg, G. and Jacobsen, T. S.: The Baltic Sea: an outline of its physical oceanography, Mar. Pollut. Bull., 12, 183-186, 1981.

Le Moigne, F. A. C., Cisternas-Novoa, C., Piontek, J., Maßmig, M., and Engel, A.: On the effect of low oxygen concentrations on bacterial degradation of sinking particles, Sci. Rep., 7, 16722, https://doi.org/10.1038/s41598-017-16903-3, 2017.

Legendre, L. and Gosselin, M.: New production and export of organic matter to the deep ocean: Consequences of some recent discoveries, Limnol. Oceanogr., 34, 1374-1380, 1989.

Leipe, T., Tauber, F., Vallius, H., Virtasalo, J., Uścinowicz, S., Kowalski, N., Hille, S., Lindgren, S., and Myllyvirta, T.: Particulate organic carbon (POC) in surface sediments of the Baltic Sea, Geo-Mar. Lett., 31, 175-188, 2011.

Lenz, C., Jilbert, T., Conley, D. J., Wolthers, M., and Slomp, C. P.: Are recent changes in sediment manganese sequestration in the euxinic basins of the Baltic Sea linked to the expansion of hypoxia?, Biogeosciences, 12, 4875-4894, https://doi.org/10.5194/bg-12-4875-2015, 2015.

Leppanen, J., Rantajarvi, E., Maunumaa, M., Larinmaa, M., and Pajala, J.: Unattended algal monitoring system-a high resolution method for detection of phytoplankton blooms in the Baltic Sea, Wiley-IEEE Press, Piscataway, New Jersey, USA, I/461463, vol. 461, 13-16 September 1994.

Lignell, R. R., Heiskanen, A.-S., Kuosa, H., Kuuppo-Leinikki, P., Pajuniemi, R., and Uitto, A.: Fate of phytoplankton spring bloom: Sedimentation and carbon flow in the planktonic food web in the northern Baltic, Mar. Ecol. Prog. Ser., 94, 239-252, https://doi.org/10.3354/meps094239, 1993.

Lindroth, P. and Mopper, K.: High performance liquid chromatographic determination of subpicomole amounts of amino acids by precolumn fluorescence derivatization with ophthaldialdehyde, Anal. Chem., 51, 1667-1674, 1979.

Logan, B. E., Passow, U., Alldredge, A. L., Grossartt, H.-P., and Simont, M.: Rapid formation and sedimentation of large aggregates is predictable from coagulation rates (half-lives) of transparent exopolymer particles (TEP), Deep-Sea Res. Pt. II, 42, 203-214, 1995.

Long, R. A. and Azam, F. Abundant protein-containing particles in the sea, Aquat. Microb. Ecol., 10, 213-221, 1996.

Mari, X. and Burd, A.: Seasonal size spectra of transparent exopolymeric particles (TEP) in a coastal sea and comparison with those predicted using coagulation theory, Mar. Ecol. Prog. Ser., 163, 63-76, https://doi.org/10.3354/meps163063, 1998.

Mari, X., Rassoulzadegan, F., Brussaard, C. P. D., and Wassmann, P.: Dynamics of transparent exopolymeric particles (TEP) production by Phaeocystis globosa under N- or P-limitation: a controlling factor of the retention/export balance, Harmful Algae, 4, 895-914, 2005.

Martin-Jézéquel, V., Hildebrand, M., and Brzezinski, M. A.: Silicon metabolism in diatoms: implications for growth, J. Phycol., 36, 821-840, 2000.

Matthäus, W. and Franck, H.: Characteristics of major Baltic inflows - a statistical analysis, Cont. Shelf. Res., 12, 1375-1400, 1992.

Matthäus, W., Nehring, D., Feistel, R., Nausch, G., Mohrholz, V., and Lass, H. U.: The Inflow of Highly Saline Water into the Baltic Sea, in: State and Evolution of the Baltic Sea, 1952-2005, Wiley-Interscience, Hoboken, 2008. 
McDonnell, A. M. P., Boyd, P. W., and Buesseler, K. O.: Effects of sinking velocities and microbial respiration rates on the attenuation of particulate carbon fluxes through the mesopelagic zone, Global. Biogeochem. Cy., 29, 175-193, 2015.

Mohrholz, V., Naumann, M., Nausch, G., Krüger, S., and Gräwe, U.: Fresh oxygen for the Baltic Sea-An exceptional saline inflow after a decade of stagnation, J. Marine Syst., 148, 152-166, 2015.

Myllykangas, J.-P., Jilbert, T., Jakobs, G., Rehder, G., Werner, J., and Hietanen, S.: Effects of the 2014 major Baltic inflow on methane and nitrous oxide dynamics in the water column of the central Baltic Sea, Earth Syst. Dynam., 8, 817-826, https://doi.org/10.5194/esd-8-817-2017, 2017.

Nausch, M., Nausch, G., Lass, H. U., Mohrholz, V., Nagel, K., Siegel, H., and Wasmund, N.: Phosphorus input by upwelling in the eastern Gotland Basin (Baltic Sea) in summer and its effects on filamentous cyanobacteria, Estuar. Coast. Shelf S., 83, 434-442, 2009.

Neretin, L. N., Pohl, C., Jost, G., Leipe, T., and Pollehne, F.: Manganese cycling in the Gotland Deep, Baltic Sea, Mar. Chem., 82, 125-143, 2003.

Passow, U.: Species-specific sedimentation and sinking velocities of diatoms, Mar. Biol., 108, 449-455, 1991.

Passow, U.: Production of transparent exopolymer particles (TEP) by phyto- and bacterioplankton, Mar. Ecol. Prog. Ser., 236, 1-12, https://doi.org/doi:10.3354/meps236001, 2002.

Passow, U. and Alldredge, A. L.: A dye-binding assay for the spectrophotometric measurement of transparent exopolymer particles (TEP), Limnol. Oceanogr., 40, 1326-1335, 1995.

Pohl, C., Löffler, A., and Hennings, U.: A sediment trap flux study for trace metals under seasonal aspects in the stratified Baltic Sea (Gotland Basin; $57^{\circ} 19.20^{\prime} \mathrm{N} ; 2^{\circ} 03.00^{\prime} \mathrm{E}$ ), Mar. Chem., 84, 143-160, 2004.

Prieto, L., Ruiz, J., Echevarría, F., García, C. M., Bartual, A., Gálvez, J. A., Corzo, A., and Macías, D.: Scales and processes in the aggregation of diatom blooms: high time resolution and wide size range records in a mesocosm study, Deep-Sea Res. Pt. I, 49, 1233-1253, 2002.

Redfield, A. C., Ketchum, B. H., and Richards, F. A.: The Influence of Organisms on the Composition of the Sea Water, in: The Sea, edited by: Hill, M. N., Interscience Publishers, New York, 1963.

Richardson, L. L., Aguilar, C., and Nealson, K. H.: Manganese oxidation in $\mathrm{pH}$ and $\mathrm{O}_{2}$ microenvironments produced by phytoplankton, Limnol. Oceanogr., 33, 352-363, 1988.

Sandberg, J., Elmgren, R., and Wulff, F.: Carbon flows in Baltic Sea food webs - a re-evaluation using a mass balance approach, J. Marine Syst., 25, 249-260, 2000.

Schmale, O., Krause, S., Holtermann, P., Power Guerra, N. C., and Umlauf, L.: Dense bottom gravity currents and their impact on pelagic methanotrophy at oxic/anoxic transition zones, Geophys. Res. Lett., 43, 5225-5232, 2016.

Shaffer, G.: Phosphate pumps and shuttles in the Black Sea, Nature, 321, 515-517, https://doi.org/10.1038/321515a0, 1986.
Sharp, J. H.: Improved analysis for "particulate" organic carbon and nitrogen from seawater, Limnol. Oceanogr., 19, 984-989, 1974.

Solorzano, L.: Determination of Ammonia in Natural Waters by the Phenolhypochlorite Method, Limnol. Oceanogr., 14, 799-801, 1969.

Stigebrandt, A.: Computations of oxygen fluxes through the sea surface and the net production of organic matter with application to the Baltic and adjacent seas, Limnol. Oceanogr., 36, 444-454, 1991.

Strickland, J. D. and Parsons, T. R.: Determination of dissolved oxygen, in: A Practical Handbook of Seawater Analysis, Fisheries Research Board of Canada, Nanaimo, British Columbia, 1968.

Strickland, J. D. H., Parsons, T. R., and Strickland, J. D. H.: A practical handbook of seawater analysis, Fisheries Research Board of Canada, Ottawa, 1972.

Struck, U., Pollehne, F., Bauerfeind, E., and v. Bodungen, B.: Sources of nitrogen for the vertical particle flux in the Gotland Sea (Baltic Proper) - results from sediment trap studies, J. Marine Syst., 45, 91-101, 2004.

Tamelander, T., Spilling, K., and Winder, M.: Organic matter export to the seafloor in the Baltic Sea: Drivers of change and future projections, Ambio, 46, 842-851, 2017.

Thomas, H. and Schneider, B.: The seasonal cycle of carbon dioxide in Baltic Sea surface waters, J. Marine Syst., 22, 53-67, 1999.

Trull, T. W., Bray, S. G., Buesseler, K. O., Lamborg, C. H., Manganini, S., Moy, C., and Valdes, J.: In situ measurement of mesopelagic particle sinking rates and the control of carbon transfer to the ocean interior during the Vertical Flux in the Global Ocean (VERTIGO) voyages in the North Pacific, DeepSea Res. Pt. II, 55, 1684-1695, 2008.

Turner, J. T.: Zooplankton fecal pellets, marine snow, phytodetritus and the ocean's biological pump, Prog. Oceanogr., 130, 205-248, 2015.

van Hulten, M., Middag, R., Dutay, J.-C., de Baar, H., Roy-Barman, M., Gehlen, M., Tagliabue, A., and Sterl, A.: Manganese in the west Atlantic Ocean in the context of the first global ocean circulation model of manganese, Biogeosciences, 14, 1123-1152, https://doi.org/10.5194/bg-14-1123-2017, 2017.

Van Mooy, B. A. S., Keil, R. G., and Devol, A. H.: Impact of suboxia on sinking particulate organic carbon: Enhanced carbon flux and preferential degradation of amino acids via denitrification, Geochim. Cosmochim. Ac., 66, 457-465, 2002.

Wasmund, N.: Occurrence of cyanobacterial blooms in the baltic sea in relation to environmental conditions, Int. Rev. Ges. Hydrobio., 82, 169-184, 1997.

Wasmund, N. and Uhlig, S.: Phytoplankton trends in the Baltic Sea, ICES J. Mar. Sci., 60, 177-186, https://doi.org/10.1016/S10543139(02)00280-1, 2003.

Wilhelm, W. L.: Die Bestimmung des im Wasser gelösten Sauerstoffes, Ber. Dtsch. Chem. Ges., 21, 2843-2854, 1888. 